\title{
تأثير العلاج العقلاني الانففالي السلوكي في التأهيل النفسي والاجتماعي لمرضى الاكتئاب
}

\author{
مر.د.وفاء شاكر عبل الكريم \\ وزارة التعليم العالي والبحث العلمي/ جامعة القاسم الخضراء \\ Wafaa.shakeer@gmail.com
}

DOI: https://doi.org/10.36473/ujhss.v60i4.1833

تاريخ الاستلام : 13/ 10/ 2020

تاريخ القبول : 12 12 2020

(c)

This work is licensed under a Creative Commons Attribution 4.0 International License

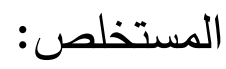

يستهدف البحث الحالي تعرّف اثر أسلوب العلاج العقلاني والانفعالي للعالم Elis في التأهيل النفسي والاجتماعي لمرضى الاكتئاب المراجعين إلى (مستشفى ابن رشد للإمراض

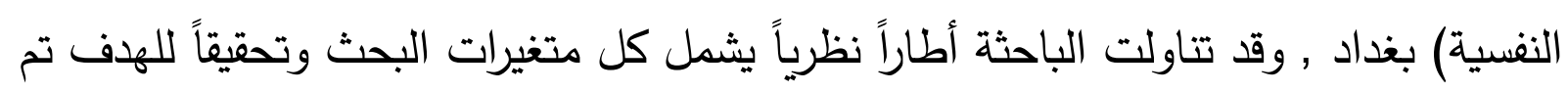
بناء مقياس التأهيل النفسي والاجتماعي , وقد اتبعت الباحثة الخطوات العلمية في بناء المقياس، فضلاً عن معرفة مؤشرات صدق وثبات المقياس، وقد تم الاستعانة بعينة التحليل

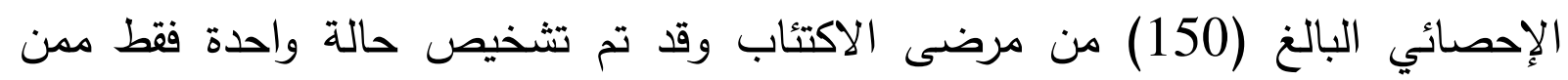
حصلت على أدنى الدرجات تطبيق البرنامج عليها , وكذلك بناء البرنامج العلاجي وفق هن الإن المشكلات المطروحة بأسلوب العلاج الفردي على عينة البحث , أظهرت النتائج أن البرنامج العلاجي كان فاعلاً في أعادة التأهيل النفسي والاجتماعي للمصابين باضطراب الاكتئاب . الكلمات الافتتاحية : العلاج العقلاني الانفعالي - التأهيل النفسي والاجتماعي - الاكتئاب 


\title{
The Effect of Rational Emotional Behavioral Therapy on the Psychological and Social Rehabilitation of Depressed Patients
}

\author{
Dr. WAFFA SHAKIR ABDUALKAREEM \\ Ministry of Higher Education and Scientific Research Al Qasim Green University \\ Wafaa.shakeer@gmail.com
}

\begin{abstract}
The current research aims to identify the effect of the rational and emotional treatment method. The scientist Elis in the psychological and social rehabilitation of patients with depression returning to (Ibn Rushd Psychiatric Hospital) Baghdad, and the researcher dealt with a theoretical framework that includes all research variables In order to achieve the aim of the research, the Psychosocial Rehabilitation Scale was built, and the researcher followed the scientific steps in building the scale, as well as knowing indicators the validity and reliability of the scale.

A sample of statistical analysis of (150) was used from the depressed patients with one condition diagnosed with the lowest score

To implement the program on them, as well as build the treatment program according to the problems presented with the individual treatment method on the research sample, the results showed that the treatment program was effective In the psychosocial rehabilitation of people with depressive disorder.
\end{abstract}

Kew Words: rational and emotional treatment - psychological and social rehabilitation - depression

\section{المحور الأول}

مشكلة البحث

يقصد بالتأهيل النفسي والاجتماعي عملية مسـاعدة الأفراد للوصـول إلى حالة من

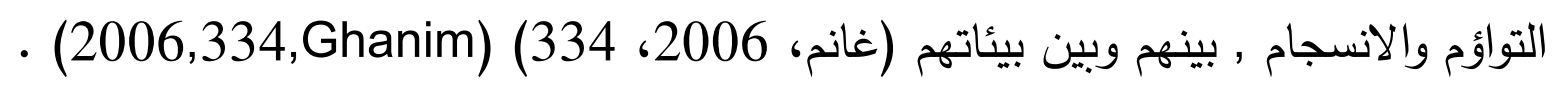

ولإشباع حاجات الفرد ومطالبه يحتاج إلى عدة وسائل... من خلال هذه الوسائل يمر

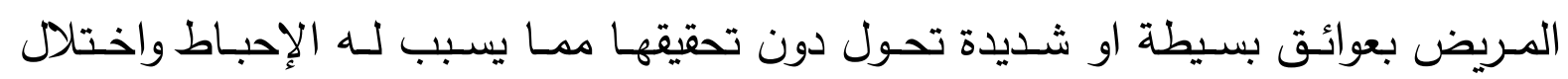

التوازن، وقدرته على تخطي هذه العوائق تتوقف على مرونة شخصيته في التكيف , اما

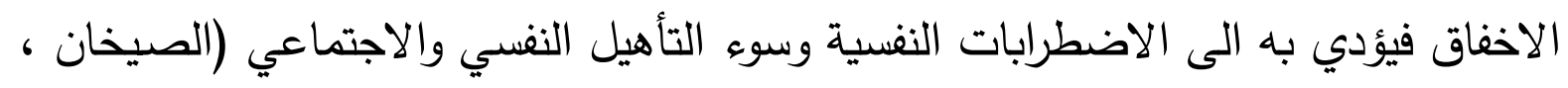

(2013,20,Al-sekhan) 2013

وتعد الاضطرابات النفسية والعقلية من اشد العوامل عنفاً في انتزاع سعادة الإنسـان

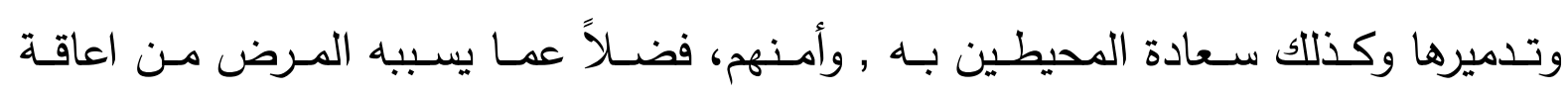

الانتاجية للفرد (الداهري، 2013، 249)(2013,249.Al-Dahery). 
أكد سوليفان ان الاكتئاب سببه يكمن في العلاقات الشخصية للمريض في نقطة زمنية

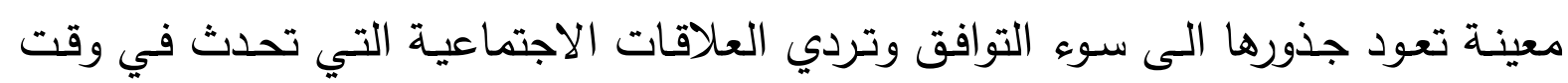

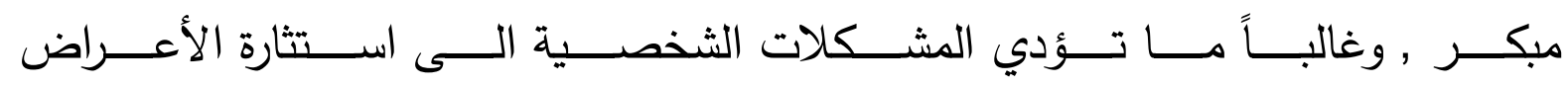

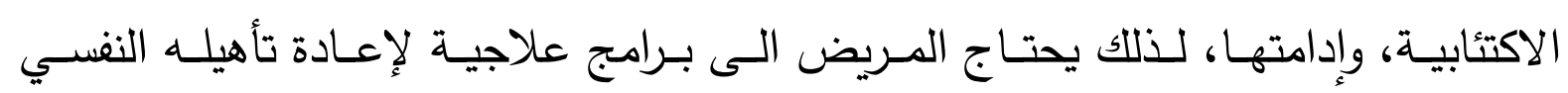

والاجتماعي كي يقل شعوره باليأس ويخف الاكتئاب لديا(2000,Davison, 288) إن المشكلة الحقيقية لاضطراب الاكتئاب تكمن في اقتصار العلاج على الأدوية دون

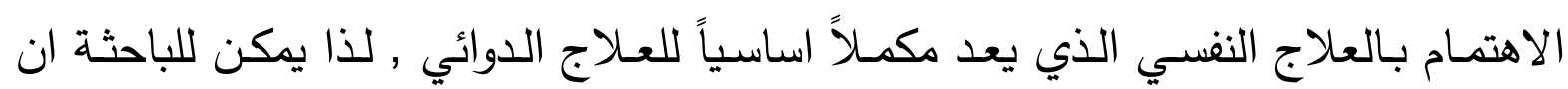
تلخص مشكلة بحثها في الإجابة عن السؤال التالي : هل ان استعمال العلاج العقلاني الانفعال السلوكي يمكن ان يُحدث تأثيراً في التأهيل النفسي والاجتماعي لمرضى الاكتئاب؟ أهمية البحث يقاس التأهيل النفسي والاجتماعي بقدرة الفرد على مواجهة المشكلات وحلها وتقبلها , والأمر غير العادي هو فشل الفرد في حل المشكلات او عجزه من ان يتعلم كيف يتعايش ولفي

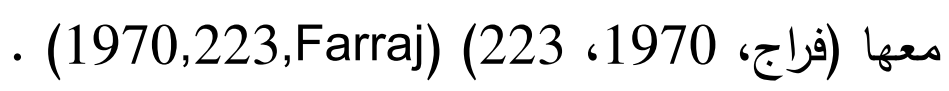
ويتحـد التأهيل النفسي والاجتمـاعي تبعـاً لمـدى نجـاح الأسـاليب التي يتبعها الفـرد للوصول الى حالة من الاتزان النفسي مع البيئة، ويسعى العلاج النفسي الى اعلى ادئس التأهيل

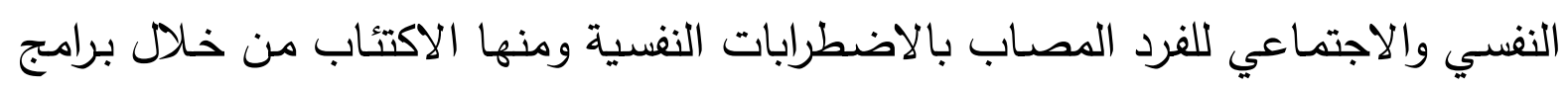

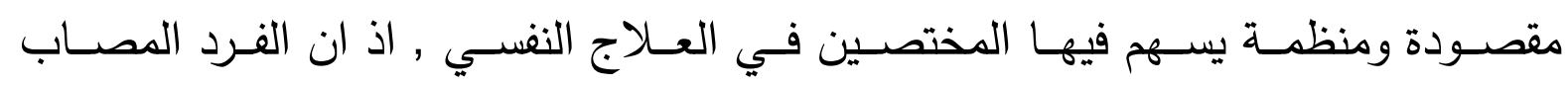
بالاكتئاب قد يتعرض تأهيله النفسي والاجتماعي للخطر , فكل انسان يحتاج الى الارشاد

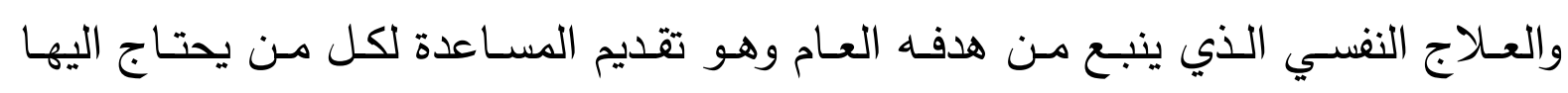
(1983,777,Dafedof)

ويشير (Elis) إلى أن هناك مجموعة من الافكار غير العقلانية لدى بعض الافراد ,

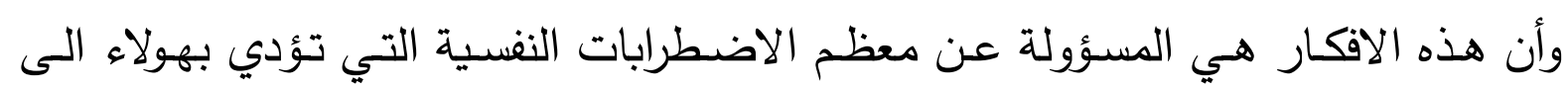

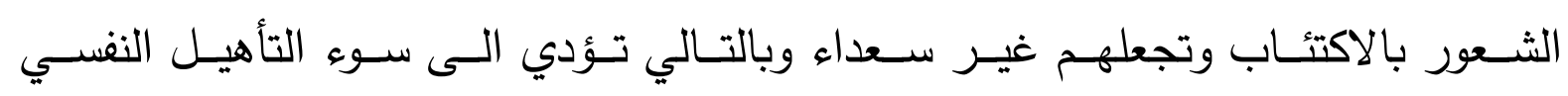


والاجتماعي (الشاوي، وقاسم ححم، 2000، 169) Alshawy\& Qasim Mohamed), . $(2000,169$ ويسعى العـلاج العقلانـي والانفعالي السلوكي الى اكسـاب الفرد المعرفـة والمهارة في التفكير من خلال تتمية قدرته على توجيه الذات والتحمل وتحمل المسؤولية الذاتية بشأن الاضطرابات ويكسبه المرونة في التفكير وتقبل الذات والالتزام ( 1989,131,Veruon) •

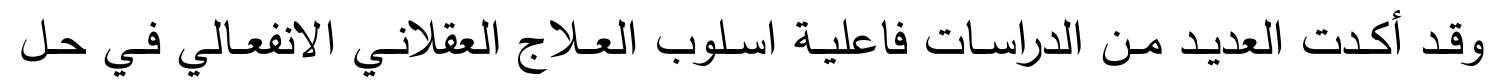
المشكلات التي يعاني منها الافراد ومنهـا دراسـة الطـائي (2005)، (والتي اسفرت عن فاعلية العلاج العقلاني والانفعالي في خفض مستوى الغضب لدى طلبة المرحلة المتوسطة

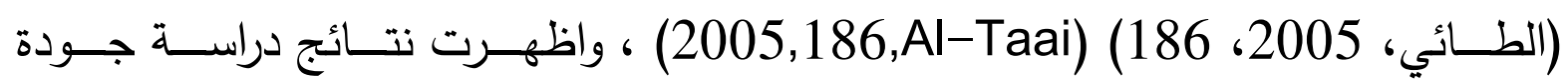
(2008) فاعلية اسلوب العلاج العقلاني والانفعالي في تتمية الصلابة النفسية لدى طلاب المرحلة الإعدادية (جودة، 2008، 187) (2008,187,Joda).

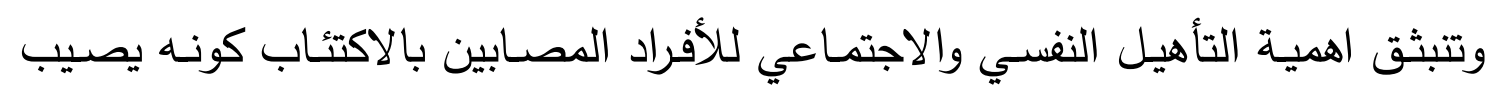
الافراد في كل الاعمار , مما يتطلب ذلك مساعدة الفرد على الاستبصار بوضعه المرضي

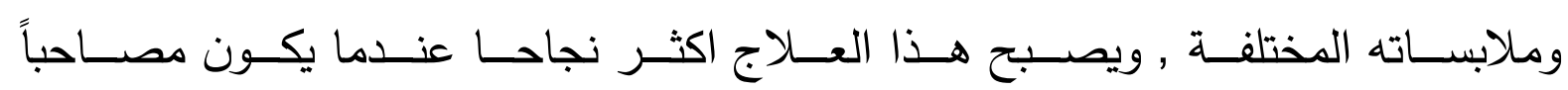

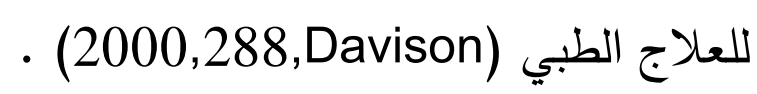

وبناءاً على ما ذكر يمكن تلخيص أهمية البحث الحالي بالنقاط الآتية :-

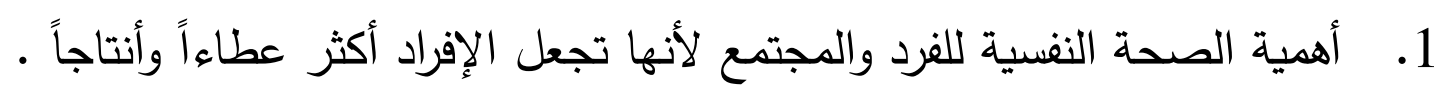
2. أهمية التأهيل النفسي والاجتماعي للافراد والمصابين بالاكتئاب .

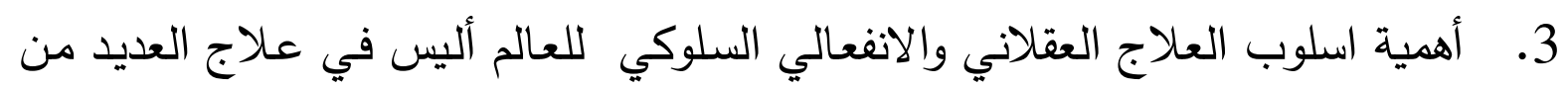

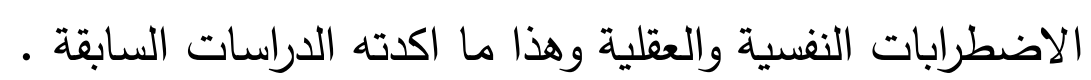

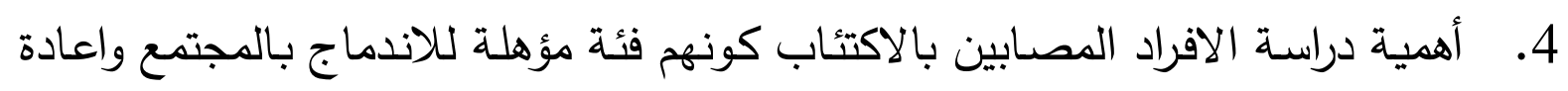
تأهيلهم النفسي والاجتماعي.

$$
\text { يستهدف البحث الحالي ما يأتي:-- }
$$

1. قياس التأهيل النفسي والاجتماعي لدى المرضى المصابين الاكتئاب . لابئ 
2. تعرف تأثير اسلوب العلاج العقلاني والانفعالي السلوكي للعالم (Ellis) في التأهيل النفسي والاجتماعي لمرضى الاكتئاب وذلك من خلال التحقق من الفرضية الاتية :-

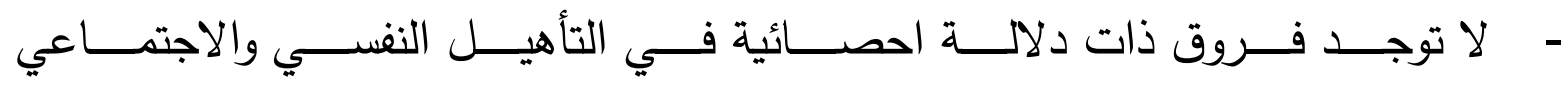
لمرضى الاكتئاب قبل تطبيق البرنامج العلاجي (وفق اسلوب Ellis) واثنائه خلال مدة

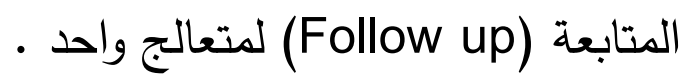
حدود البحث

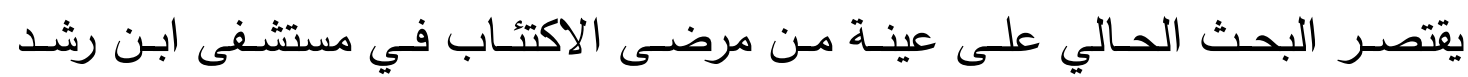
التدريبي للأكراض النفسية للعام (2017-2018) تحديد المصطلحات اولاً : تأثير Effect

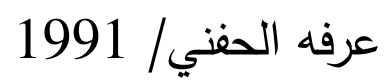
بان مقدار التغيير الذي يطرأ على المتغير التابع بعد تعرضه لتأثير المتغير المستقل .

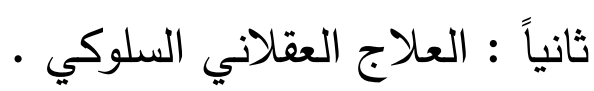
عرفه 1980 Ellis هو عبارة عن العملية التي تهدف الى تزويد المسترشد بالمهارات التي تساعده على تحديد أفكاره اللاعقلانية ومواجتها واستبدال تلك الأفكار بأخرى عقلانيـة , ومنطقية باستخدام العمليات العقلية فالإنسان لديه القدرة على تجنب الاضطرابات الانفعالية

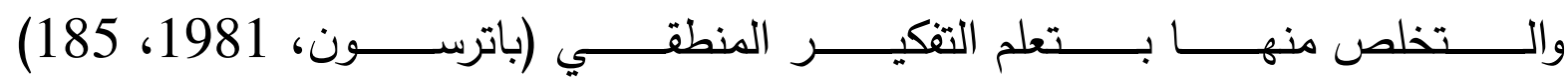
(1981,185,Paterson) التعربف الإجرائي مجموعة من التثنيات والإجراءات المعرفية السلوكية التي تستعملها الباحثة في اعادة التأهيل النفسي والاجتماعي وتخفيف شدة اعراض الاكتئاب لمرضسى الاكتئاب فضـلاً عن لن

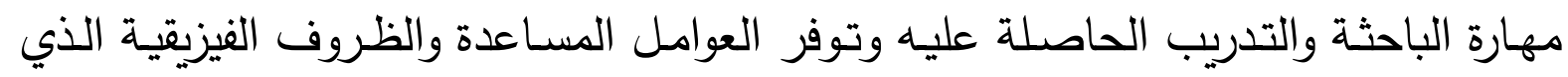
يقاس بالارجة والفرق في درجات الاختبارات القبلية والبعدية لكل فرد . ثالثاً : التأهيل النفسي والاجتماعي 
عرفـه سـوليفان 1987 Sullifan عمليـة ديناميكيـة تقـوم علـى أسـاس العلاقـات الشخصية المتبادلة التي يقيمها الفرد مـع الآخرين يسعى من خلالها إلى اشباع حاجاته

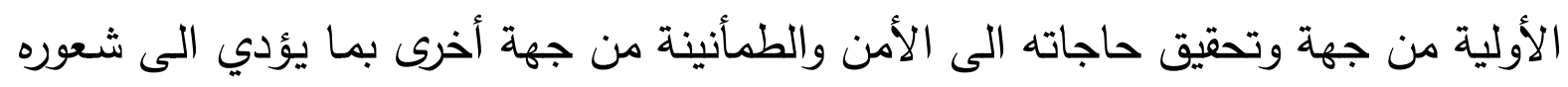

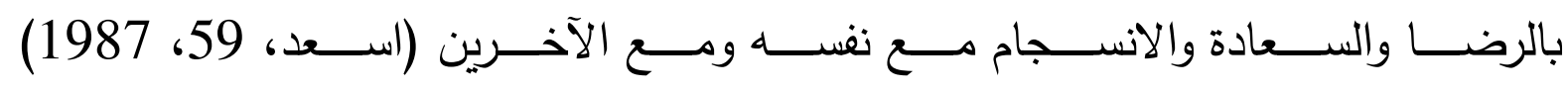
$(1987,59$, Asaad)

\section{-}

الدرجة الكلية التي يحصل عليها المستجيب (المراجع) من أفراد عينـة البحث من

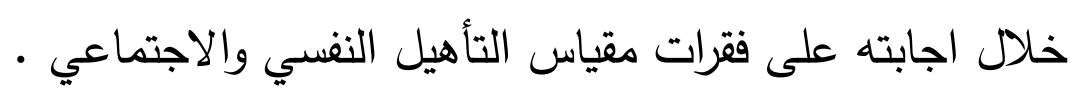

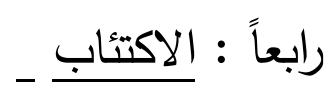

عرفته منظمـة الصـحة العالميـة في تصـنيفها الـدولي العاشـر (1994-15- ICD) انحطاط في المريض وفقر اهتماماته وعدم تمتعه بما يبهج الآخرين وتتفاوت تلك الإعراض

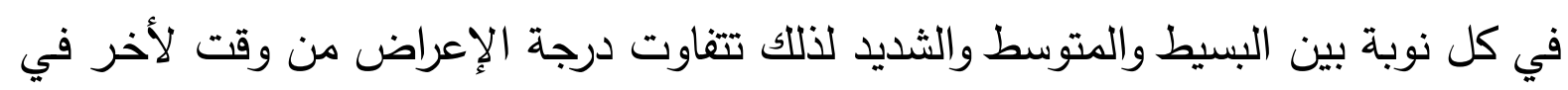
الثخص الواحد أثناء نوبة الاكتئاب وتتلخص هذه الإعراض في هبوط القدرة على التركيز والانحطاط تقدير المريض لذاته وثقته بنفسه ومعاناته من الإحساس , وعدم أهميته والتشاؤم وسـرعة الانهاك او انعدام القوة والتفكير في إيذاء نفسـه , بمـا فيه إقدامسه على الانتحسار

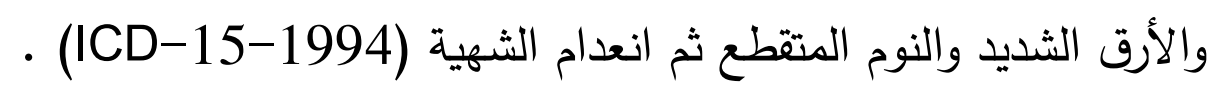
المحور الثاني العلاج العقلاني الانفعالي:

يعد اسلوب العـلاج العقلاني الانفعالي احد اسـاليب تعديل السلوك المعرفي والذي الذي اسفرت العديد من الدراسات عن فاعليته بصفة عامسة سواء استخدم بمفرده او مع اسـاليب اخرى (جودة، 2008، 8) (2008,8,Joda) .على دراسة الافكار والمشاعر والاعتقادات

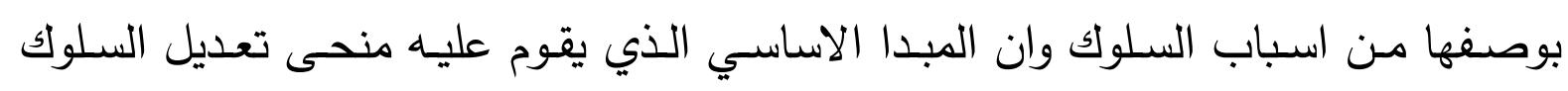

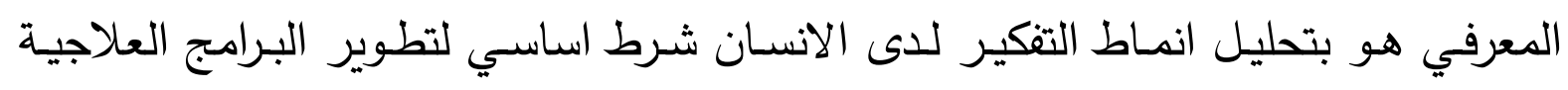
الفعالة (الخطيب، 1995، 249) (1995,249,Al-Khateeb). 
وان سلوكيات الفرد هي نتاج للافكار والاتجاهـات اللامنطقيـة لذا فعندما يراد فهم

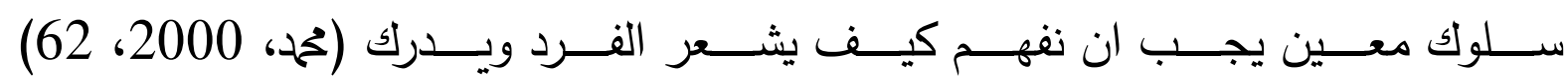
- $(2000,62$,Mohameed) لذا وجدت دراسـات علاقـة ذات دلالـة احصـائية بين الافكار اللاعقلانيـة وبين الاكتئاب، كدراسـة ادوارد وويـل (Edward ～～W Will, 1998, 137-142) ودراسـة مـاركوت (Marcotte) يسعى العلاج العقلاني السلوكي الى محاولة اقناع الفرد بان معظم المشكلات التي يعـاني منهـا تعود الى معتقدات خاطئة وتصـورات ذهنيـة فلسـفية لا تسـتـد الى الحقـائق الموضوعية، فالشعور بالاكتئاب يمثل اعراضاً للمشكلة الرئيسية المتمثلة في الافكار التي يحملها الانسان حول طبيعة المواقف التي يواجهها. (Ellis \& Bernard, 1992, 155).

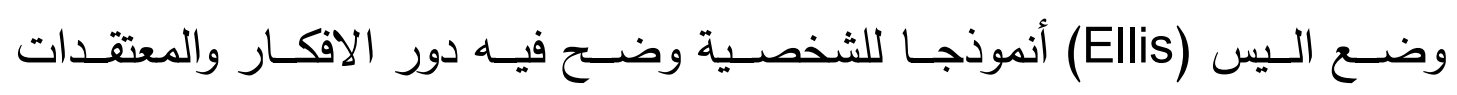
اللاعقلانية في الاضطرابات الانفعالية والذي عبر عنه بالرموز (A- B-C) اشارة الى الخطوات الثلاثة التي تستعمل في خلق الاستجابات المضطربة اذ يمثل:

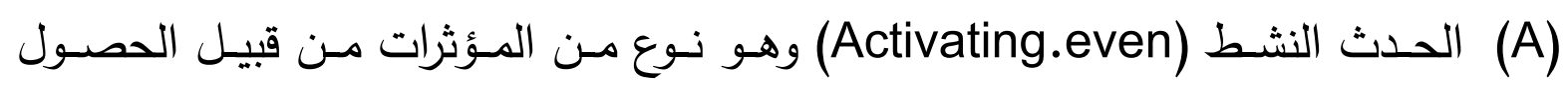

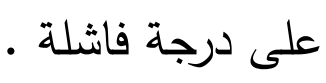

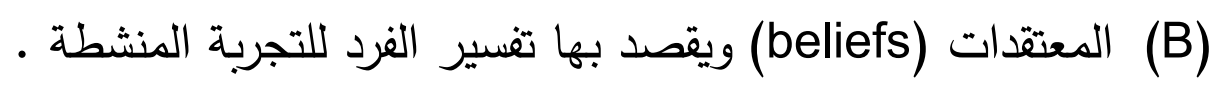
(Consequences) حدوث الاضطراب او الضيق النفسي. (العزة، وجودت، (C) • (1999,141,Al-Aeza\&Jawdat) (141، 1999 ويرى اليس انهه ما لم تتوقف عن التفكير في تفسيرنا للاحداث سوف تنتقل بصورة

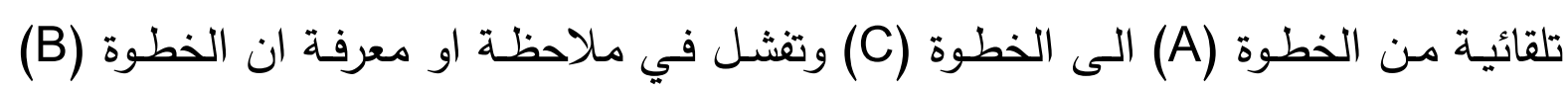
هي التي تخلق الانفعال , لأن الفشل في الامتحان لا يسبب انفعال الاكتئاب وأنما الخطوة

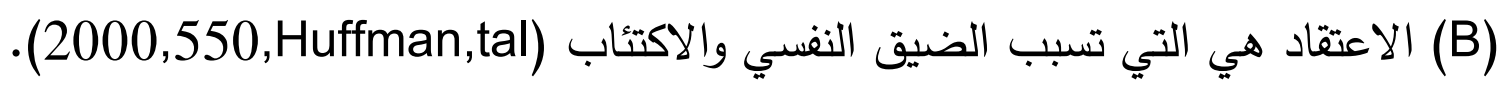
واكد اليس ان الاضطرابات السلوكية والعاطفية هي نتاج تفكير غير منطقي الذي

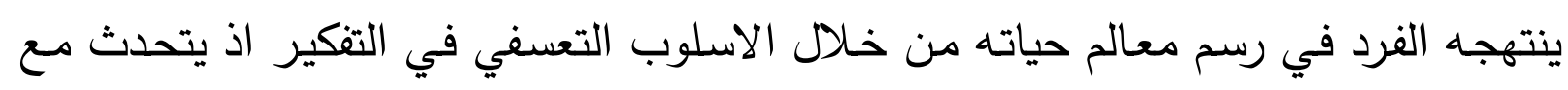

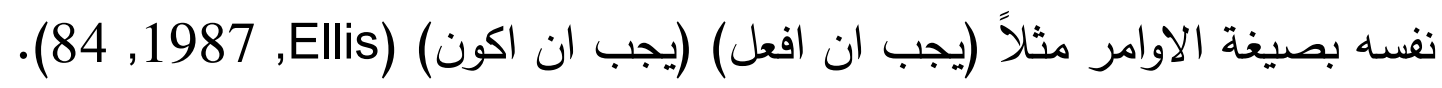


Ellis الاساليب العلاجية عند اليس

يركز أسلوب العـلاج العقلاني الانفعالي للعـالم اليس حول دحض بعض الأفكار

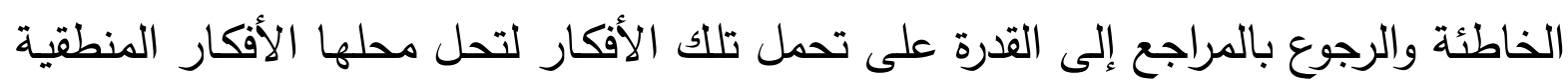
التي تتلاعم مـع البيئة التي يعيش فيها , ويـرى اليس فاعليـة هذا الاسلوب في عـلاج المشكلات النفسية كونه يتناول مكونات الشخصية (العاطفة , السلوك , الادراك) , ومن اهم الأساليب العلاجية التي قدمها اليس هي:اولاً : الأسـاليب المعرفية :- يسعى الاختصاصيون الذين يستخدمون هذا الاسلوب الى هي مساعدة المراجعين على اكتشاف طرائق التفكير الخاطئة ومن ثم مواجتتها بطرق واقعية -: من (1996,66,corey) 1. الافكـار اللاعقلانيـة :- يسـعى المعـالج هنــا الـى مجادلــة المراجـع حـول الافكـار اللاعقلانية والتي ساهمت في نشأة الاضطراب الذي يعاني منه , كذللك يعلم المراجع كيف يقوم بذلك لوحده مستقبلاً من خلال اكتشاف طرق التفكير والمعتقدات التي يؤمن لها ويبني عليها أنماط سلوكه ومشاعره.

2. الواجبات المعرفية :- وهنا يطلب المعالج من المراجع عمل قائمسة بالمشكلات التي يعاني منها , ثم النظر في كل مشكلة على حدة ومن خلال مساءلة الذات حول نشأة هذه المشكلة والطريقة التي يفكر بها لتتم مسـاعدة المراجع على تحديد نمط التفكير الخاطئ الذي ساهم في حدوث المشكلة . الني ثانياً : الأسـاليب الوجدانيـة:- يستخدم المعـالجون في أسـلوب العـلاج العقلاني الانفعـالي السـلوكي مجموعـة من الأسـاليب الانفعاليـة لمسـاعدة المراجع على تغيير مشـاعره السلبية

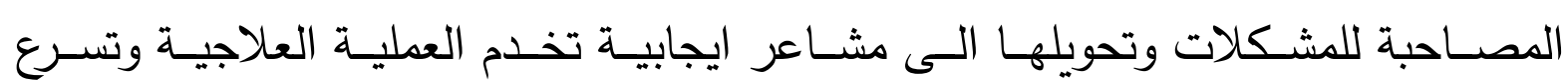

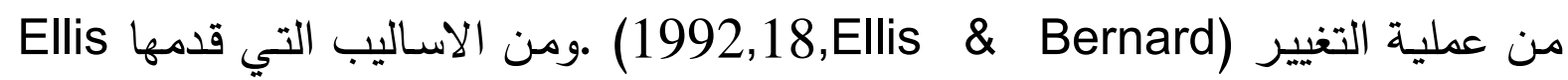
هي:- - التخيل العقلاني :- تساعد هذه العملية المراجعين على تأسيس أنماط من المشاعر من خلال مساعدتهم على تخيل التفكير المنطقي والسلوك والمشاعر ثم تطبيق ذلك واقعياً 
في الحياة ولعدة مرات في الأسبوع سوف يصل المراجيع الى حالـة من التوافق النفسي

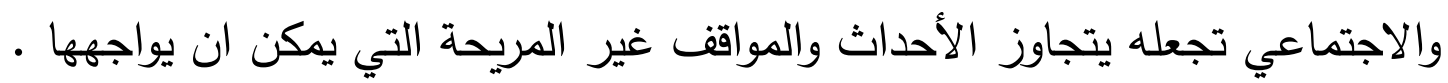

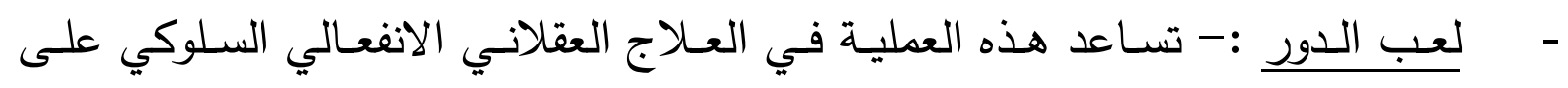

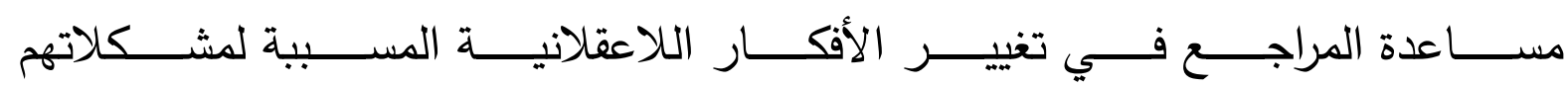
.(1988,178,Block\&Dobson) ثالثاً : الأسـاليب السـلوكية :- يسـتخدم أسـلوب العـلاج العقلانسي الانفعـالي السـلوكي الأساليب السلوكية في حدود الإطار النظري للعلاج العقلاني الانفعالي السلوكي ومن بين الأساليب السلوكية المستخدمة هي :- التدرببات المنزلية :- وهي التدريبات المنزلية النشطة التي يكلف بها المراجع , كما تتضمن التدريبات المنزلية جوانب عقلية مثل التعرف على الأفكار غير المنطقية وتدوينها - (1988,178,Block\&Dobson) - - التعزيز الاجتماعي :- هو أسلوب منظم يعمل على تقوية استجابة معينة وأن تحديد المناسبة يؤدي إلى الحصول على استجابة سلوكية مرغوبة (1983,130,Block) . - - التاهيل النفسي والاجتماعي:التاهيل يعني قدرة الفرد على اقامة علاقات اجتماعية مثمرة وممتعة يسودها الحب والعطاء

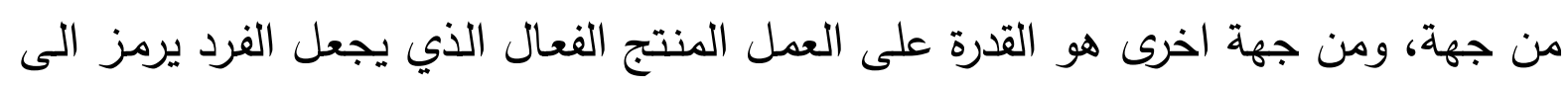

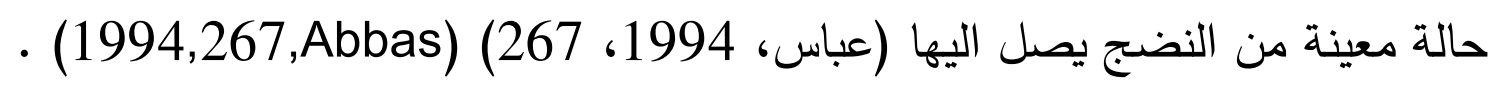

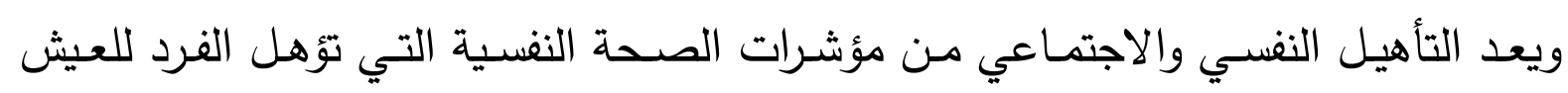

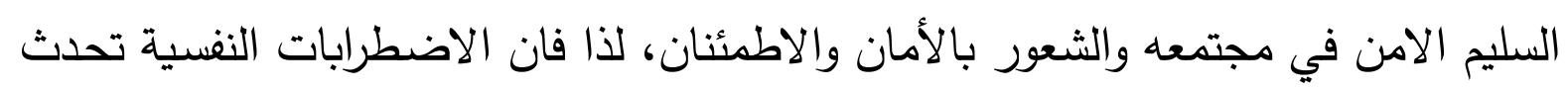

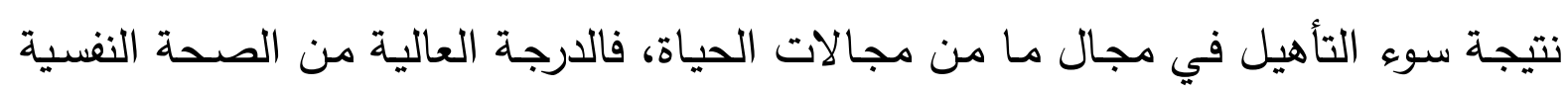

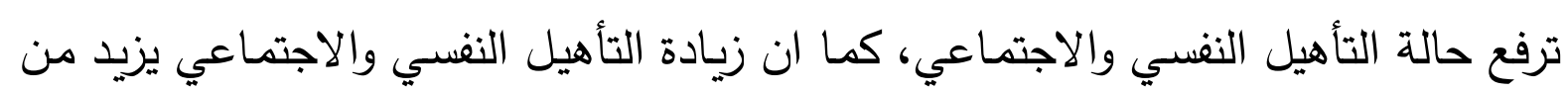

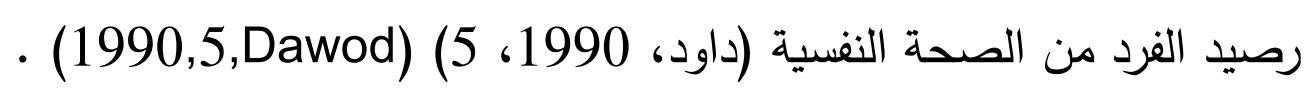
النظرية التي فسرت التأهيل النفسي والاجتماعي هاري ستال سوليفان (نظرية العلاقات الشخصية المتبادلة) 
اكد سوليفان ان بناء الشخصية هو نتيجة التفاعل مع الكائنات الاتسانية الاخرى، وان الثخصية تظهر من القوى الثخصية والاجتماعية التي تؤثر على الفرد من ميلاده، وان

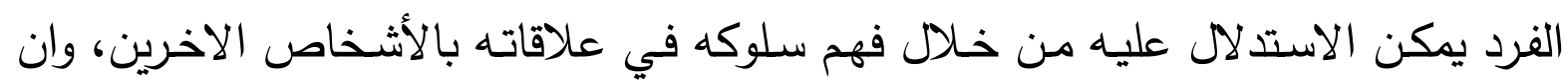
السلوك المضطرب ينشـا من الاضطرابات في هذه العلاقات، اذ يدخل الفرد في مواقف بـف لهن

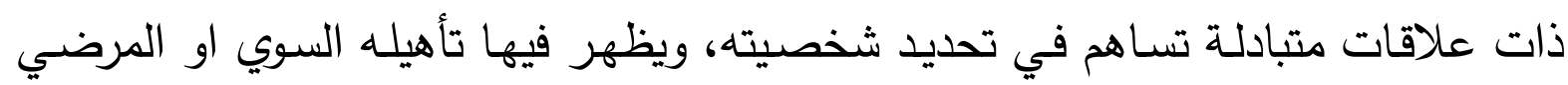
من الناحية النفسية (الموسوي، 1999، 25) (1999,25,Al-Mosawi) • واكد سوليفان ان السلوك الجيد والمنحرف يتشكل خـلال التنشئة الاجتماعيـة للفرد مـع والديه، فالبيئة الاجتماعية التي يمارس فيها الفرد نشاطه لتحقيق اشباع حاجاته البيولوجية والثقافية تساعد على تكوين شخصية ونموها والعلاقات المتبادلة التي يقيمها مع الاخرين هي علاقات ديناميكية تساعد على تكوين ونمو الذات وتؤدي الى تأهيله النغسي تلئي

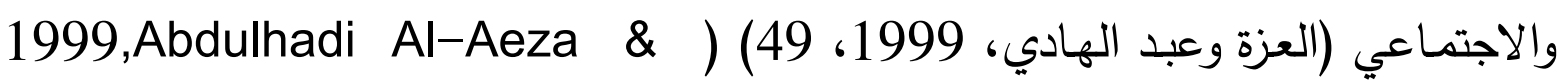

واشـار سوليفان ان نمو الشخصية يمر بعدة مراحل، هي مرحلة الحضـانة والطفولة والحداثة والمراهقة، واخيراً مرحلة النضج وتتميز هذه المرحلة بالاستقرار وتكوين الاتجاهات الثابتة ازاء المواقف والعالم، والدينامية الذاتية يكمل نموها وتتبلور (للأفضل او للأسوء) واذا تمكن الفرد من تجاوز المراحل السابقة بشكل طبيعي يكون الفرد ناضجاً ومتطبعاً اجتماعياً

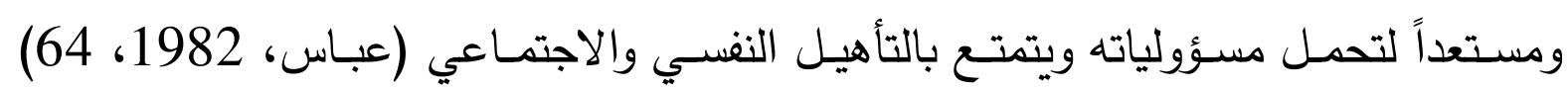
• (64,1982 .Abbas)

يعتقد سـوليفان ان السلوك المضطرب ينشـا من تفاعلات النـاس في الحياة اليومية، كمـا ينظر الـى الاضطرابات كنمـاذج مـن التصـرفات غير المناسبة في العلاقـات الشخصية المتبادلة (هول وليندزي، 1978، 148) (1987,148,Hall\&Lindsey) • تبنت الباحثة نظرية (العلاقات الشخصية المتبادلة) للعالم سوليفان للأسباب الآتية:

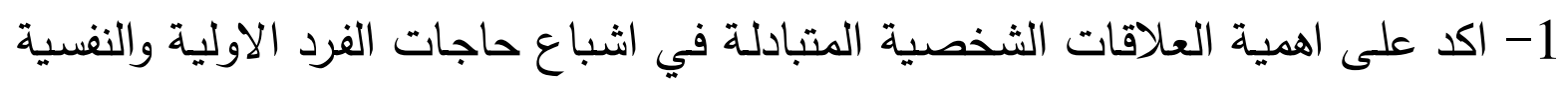
وعدم اشباعها لفترة طويلة يؤدي الى القلق والتوتر وسوء التأهيل النفسي والاجتماعي. 2- اكد على اهمية التتشئة الاسرية للفرد في التأهيل النفسي والاجتماعي. 
3- وضـع للشخصية عدة مراحل من النمو، ولكل مرحلة خصـائص معينـة تختلف عن غيرها من المراحل ومرتبطة مع المراحل اللاحقة لها، واذا استطاع الفرد تجاوز مراحل نمو مون مرد

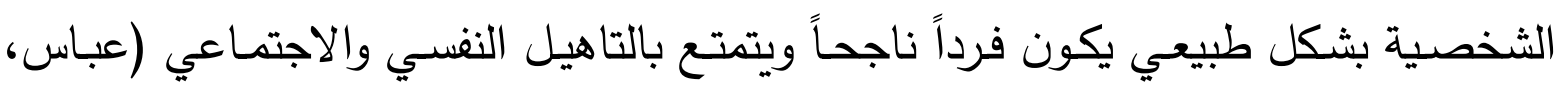
• (1982,64,Abbas) (64 1982

الاكتئاب Depression:

مرض الاكتئاب النفسي هو احد اكثر الامراض النفسية انتشـاراً في الوقت الحالي وتؤكد

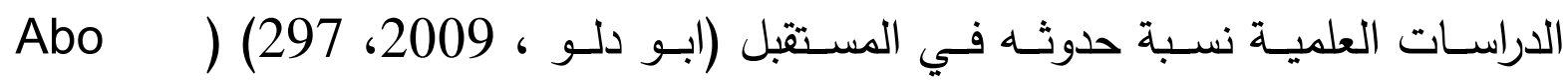
.(2009,297,Dalo

ويقدر ان ما بين 9\%-20\% من مجموع السكان يعانون بين وقت واخر على امتداد اعمارهم من اعراض اكلينيكية للاكتئاب، والاكتئاب هو اكثر التشخصيات النفسية ارتباطاً بالانتحار، اذ ان المكتئب محبط ورافض للحياة، (الخالدي، 2015، 298) (Al-Khalidi), - $(298,2015$

اذ اثتتت الدراسـات ان حوالي 50\%-70\% من محاولات الانتحار الناجحة بين المجموع العام سببها الاكتئاب، وتقدر منظمـة الصحة العالمية في دراستها المسحية للاكتئاب في العـالم ان هنـالك مـا لا يقل عن (100) مائـة مليون شـخص يعـانون من الاكتئاب وفي

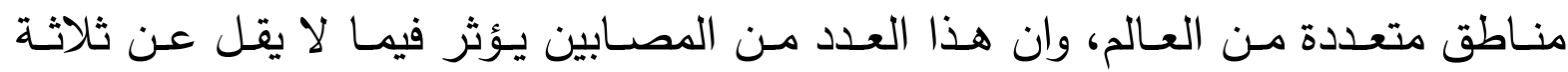
اضعاف هذا العدد في الاخرين الذين يتعاملون او يتواجدون معهم. (غانم، 2006، 103) (2006,103,Ghanim) نقلاً عن (Sartorius) أعـراض الاكتئاب

أجمع معظم الأطباء وعلماء النفس بان إعراض الاكتئاب تتمثل في :1. الانقباض واليأس والقنوط وهبوط الروح المعنويـة والحزن العميق والبكاء والتشـاؤم والتبرج بأوضاع الحياة . 2. بطء التثكير والاستجابة والحركة ثم الانطواء والوحدة والانعزال والصـت والثـرود والذهول 
3. عدم الاهتمـام واللامبالاة بالمحيط ومن حوله , وقصسور الدوافع والميول فقد يشعر

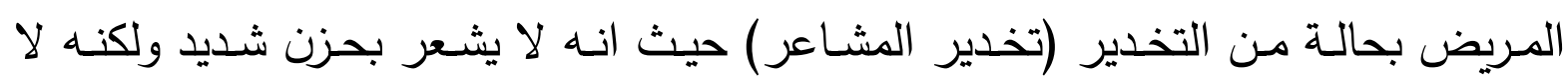
يشعر بسعادة ايضاً . مئر

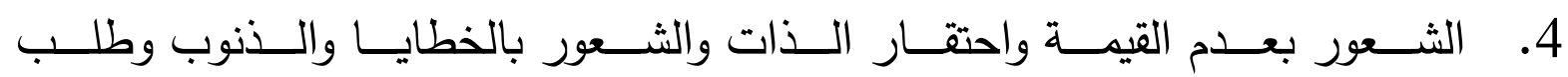

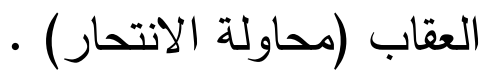
5. الشعور بالضيق وانقباض النفس وفقدان الثهية للطعام والامساك . . 6. الصداع والتعب وضعف النشاط العام • 7. اضطرابات النوم وقد تكون في صورة صعوبة النوم او كثرته .

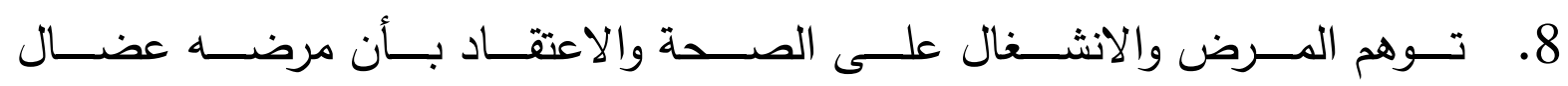
وميؤس منه (الخالدي، 2015، 211) (Al-Khalidi), 2015, 211).

Dsm-IV-1994):) معيار تشخيص الاكتئاب في ان خمسة او اكثر من الاعراض الاتية اذا لوحظت خلال مدة اسبوعين على الفرد ومثلت

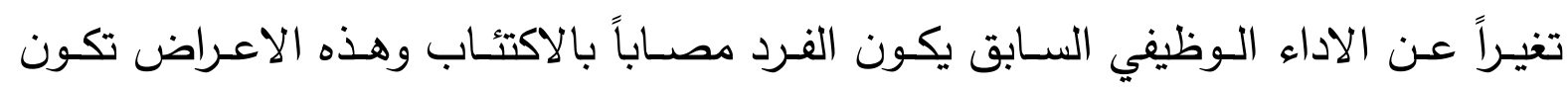

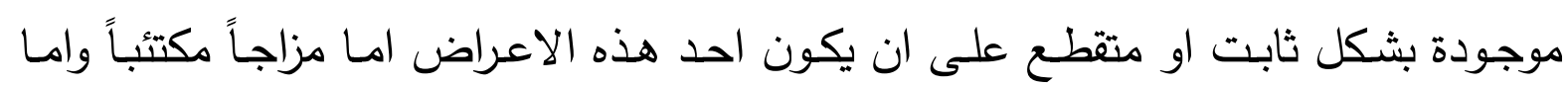

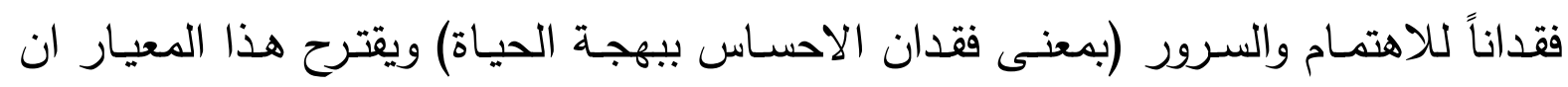
تشـخيص الاعـراض لا يرجـع الى الاثـار الفسيولوجية المباشـرة لمـادة معينـة مثل اسـاءة استعمال عقار او الى حالة طبية (1994-Dsm-IV): 356). وهذه الاعراض هي: - إن 1- مزاج اكتئابي في معظم اوقات اليوم وتقريباً كل يوم كما يؤشر اما ذاتياً او عن طريق ملاحظة الاخرين. 2- يقل الاهتمام بالبهجة والسرور بصورة عامة او في كل النشاطات تقريباً كما تشير اليه تقارير الفرد وملاحظات الاخرين. 3- نقص في الوزن بصورة ملحوظة وفقدان الشهية او زيادة في الوزن (يتغير الوزن بنسبة 5 من وزن الجسم خلال شهر) او ازدياد في الشهية خلال اليوم. 


$$
\text { 5- 5- الارق او زيادة في فترات النوم كل يوم تقريباً (اضطراب النوم). }
$$

6- الثعور بالتعب او فقدان الطاقة كل يوم تقريباً.

7- مشاعر بالدونية او الذنب غير مبرر والذي يكون وهماً كل يوم تقريباً (شعور بالاثم). 8- نقص في القدرة على التفكير والتركيز او التردد كل يوم تقريباً ويؤشر من تقرير الفرد او كما يلاحظه الاخرون. 9- افكار متكررة عن الموت (ليس فقط الخوف من الموت) وافكار انتحاريـة متكررة دون خطة محددة او محاولات انتحارية بخطة محددة الاختيار . اسباب الاكتئاب هناك عدة اسباب تتداخل معاً لظهور اعراض الاكتئاب هي: 1- اسباب عضوية

اهمها تغيرات في بعض كيميائيات المخ منها مادة (السيوتونين، والنورادينالين، الدوبامين)

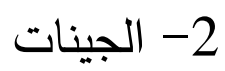
تلعب العوامل الوراثيـة دوراً مهماً في نشـأة الاضطرابات الاكتئابية، اذ ان الدراسـات التي اجريت على التوائم المتشـابهة اوضـحت مدى اهميـة العوامل الوراثيـة، فقد بينت ان نسبة الاصـابة بين التوائم المتشابهة تصل الى 65\% والتوائم المتآخية تصل إلى حوالي 14\% وتقل نسبة الاصابة بين افراد العائلة (عكاشة، 2005، 420) (Aukasha), 2005,42). وهنـاك بعض الاشخاص مدن لهم سمات تئهلهم عن غيرهم للإصـابة بالاكتئاب ومنها:

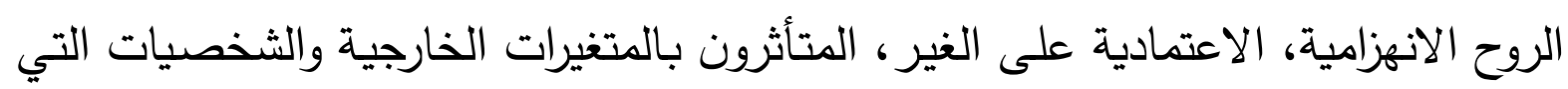

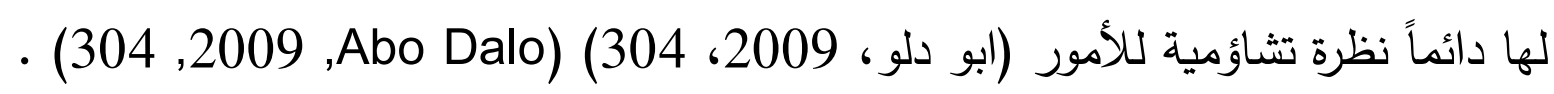

عوامل بيئية وتتمثل بكثرة الضـغوط الخارجية على الانسـان دون وجود متنفس لها تدعو الى الثـعور بعدم جدوى الحياة وكذلك كثرة التعرض للعنف والاعتداء النفسي والجسدي وكذلك احباط الدوافع لا شعورية، الى تحد لقدرات الفرد، او عدم التوافق بين قدراته وانجازاته وما يطلب 


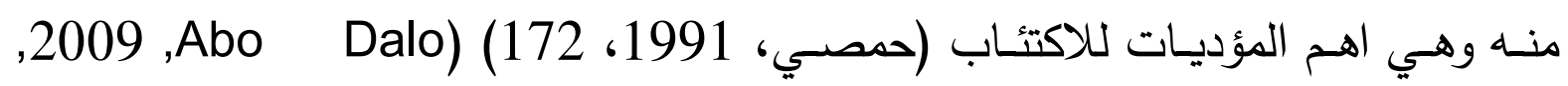
. $(304$ المحور الثالث منهجية البحث

استلزمت طبيعـة البحث الحالي أهدافه العلاجيـة استعمال المنهج الاكلينيكي , شبه التجريبي , إن المخطط شبه التجريبي يوفر بديلاً للمخططات التجريبية من حيث انه يمكن تطبيقه على مواقف ميدانيـة , ولا يقتضـي أن يملك المجرب الضـبط المطلق للمتغيـرات التجربي (حصي، 1991، 172) (1991,172,Homsy) • واتساقاً مع مشكلة البحث وأهدافه تم تحديد متغيرات البحث الحالي , اذ يعد (العلاج العقلاني الانفعالي السلوكي متغيراً مستقبلاً ,والتأهيل النفسي والاجتماعي متغير تابع وعليه اعتمدت الباحثة المنهج الاكلينكي شبه التجريبي ذي المنحى الفردي في معالجة البيانات ,

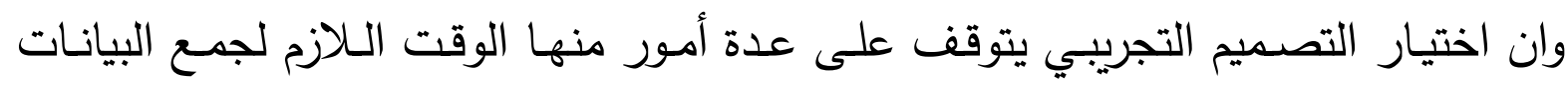
والكلفة ونسبة المعلومات إلى الكلفة وعدد المتغيرات التي يتعامل معها الباحث لاختبار العينية الصحة (التميمي، 2009، 108) (Al-Timimi, 2009, 108) • وكذلك عدد الحالات قيد الدراسـة ونوع العـلاج المستعمل والوقت الذي يصرف في

• (1983, 7,Miller) (العلاج مجتمع البحث

مدكن تحديد المجتمع الأصلي عن طريق وضع إطار للمتغيرات التي يمكن ان تتوزع

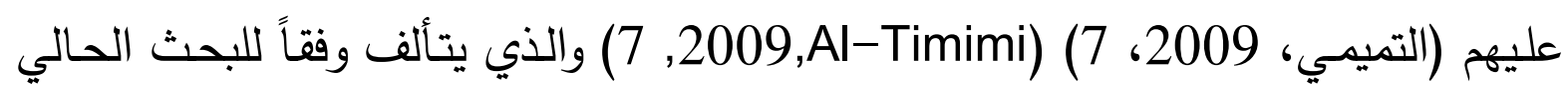
من خلوهم من اضطراب الثدة ما بعد الصدمة والعمر والتحصيل الدراسي , يتكون مجمع

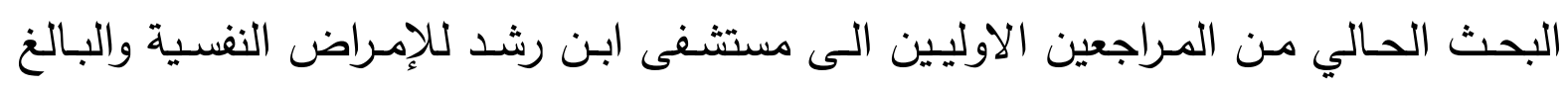
عددهم (1000) مراجع ومراجعة ب واقع (650) ذكور و (350) إناث . مجتمع البحث المستهدف عدمث

ويعرف بأنـه المجتمـع الذي سـوف تعمم عليهم نتائج البحث والمحصلة مـن العينـة (جلال، 2008، 37) (2008,37) ومن اجل تشخيص مجتمع البحث المستهدف 
كان لابد من تحديد عدد المصابين باضطراب الاكتئاب العصابي من مجتمع البحث فقد تم تحديد إعدادهم من خلال قاعدة بيانات المستثفى والبالغ عددهم (300) مراجع ومراجعة. عينة البحث

تم اختيار عينة البحث الحالي بشكل عرضي من مجموعة من المرضى المراجعين

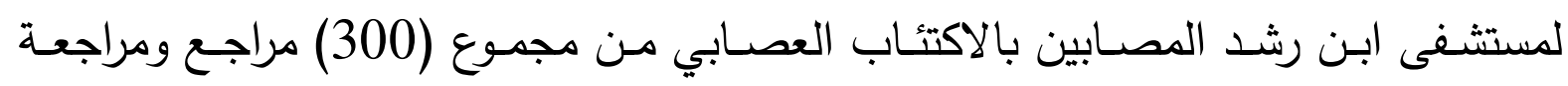
ويتضمن البحث الحالي عينتين هما :1. عينــة التحليـلـ الإحصـائي والبـالغ عـددها (150) مراجـع ومراجعـة مصــابين بالاكتئـاب العصـابي لغرض التأكد مـن مؤشـرات صـدق وثبـات المقيـاس اذ تم اختيـارهم

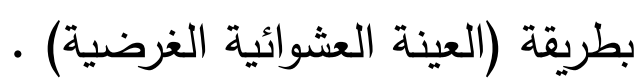

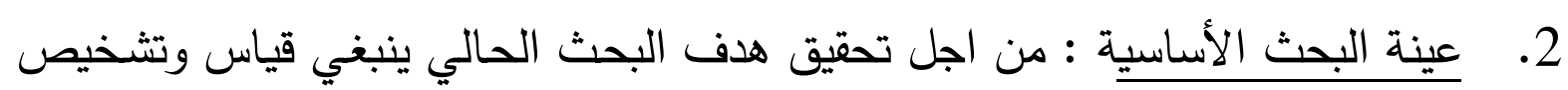

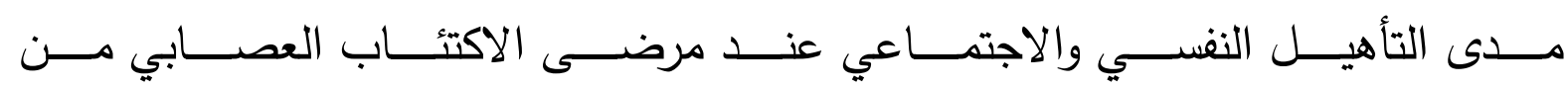
مراجعي (مستشفى ابن رشد للأمراض النفسية) بغداد , وبعد الانتهاء من تطبيق المقياس تم

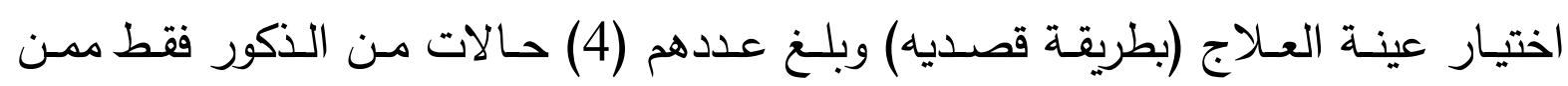
حصلوا على أدنى الدرجات على مقياس التأهيل النفسي والاجتماعي، بعد ان اجرت الباحثة

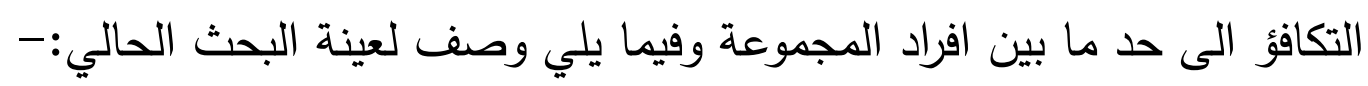

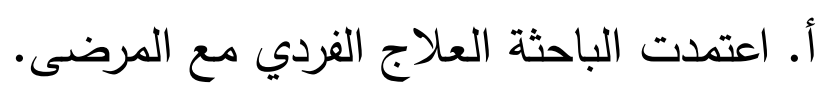
ب. تم تشخيصهم من قبل الاطباء النفسانيين بانهم يعانون من الاكتئاب العصابي. ج. كان هناك تكافؤ الى حد ما بينهم من ناحية:- العمر (50- 58 (5) سنة. - الحالة الاجتماعية (متزوجين). - حاصلين على شهادة الاعدادية. - خلوهم من اضطراب الشدة ما بعد الصدمة والاكتئاب الذهاني او نوبة اكتئاب مع هوس الهـ حسب تشخيص الاطباء. ملاحظـة (تم الاكتفاء بعرض حالـة واحدة فقط ومتابعـة تطورات تلك الحالـة على مدى الاهى جلسات البرنامج العلاجي) 


$$
\begin{aligned}
& \text { أدوات البحث } \\
& \text { يتضمن البحث الحالي أداتان هما :- }
\end{aligned}
$$

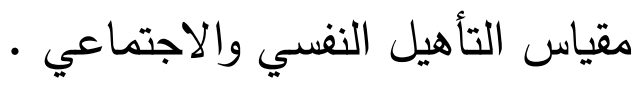

$$
\begin{aligned}
& \text { البرنامج العلاجي الباني }
\end{aligned}
$$

تم بناء البرنامج العلاجي وفق الأسس العلمية مستندة الباحثة على أسلوب العلاج العقلاني

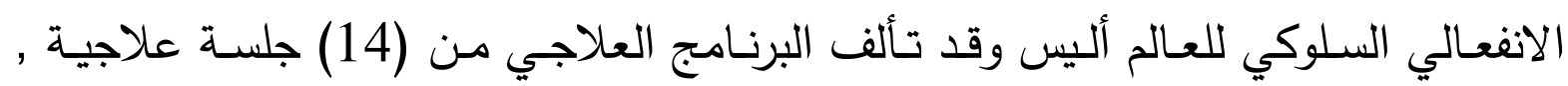

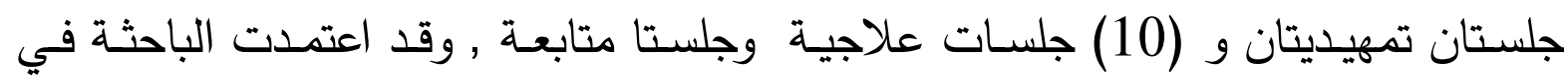
برنامجها على الحاجـات العلاجية لمتغير التأهيل النفسي والاجتمـاعي لمرضسى الاكتئاب

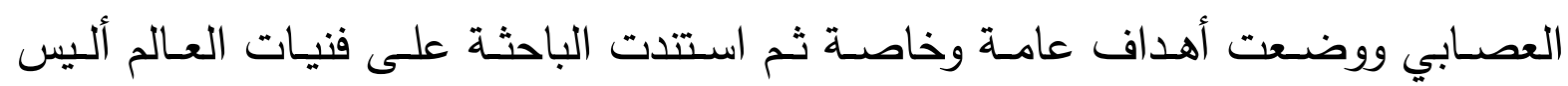
لأسـوب العـلاج العقلاني الانفعالي السلوكي , بعد تطبيق الفنيات أجرت الباحثة تقويماً

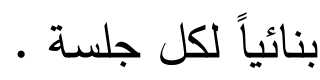
1. مقياس التأهيل النفسي والاجتمـاعي : تحقيقاً لأهداف البحث الحالي اتبعت الباحثة الخطوات العلمية في بناء المقياس وكالاتي :أولا : تحديد مفهوم التأهيل النغسي والاجتماعي . ثانياً : تحديد مجالات المقياس .

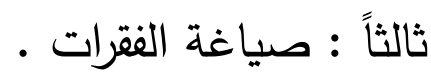
تبنت الباحثة نظريـة سوليفان (Sollivan) نظريـة العلاقات الشخصية المتبادلة في تحديد مجالات مقياس التأهيل النفسي والاجتماعي والفقرات التي تغطيها من خلال نظريـة (Sollivan)

وقد تبين إن هناك مجالين رئيسين هما 1-المجال النفسي: عملية متغيرة ومستمرة تعبر عن قدرة الفرد على تغيير سلوكه او تعديل

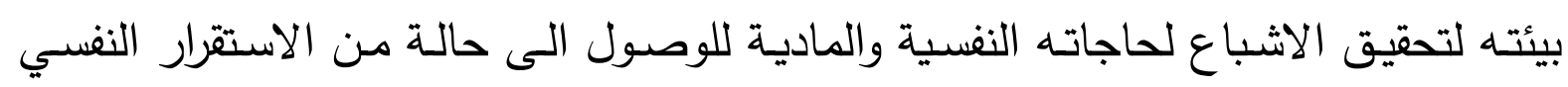
والجسمي. 
2-المجـال الاجتمـاعي: عمليـة ديناميكيـة تعبـر عـن قدرة الفـرد علـى اقامـة علاقـات اجتماعيـة مبنيـة على التفاعل والتواصل والاحترام المتبادل لاشباع حاجاته ودوافعهـ وفق الاعراف والمعايير الاجتماعية.

صياغة فقرات المقياس فضـالًا عن تبنـي الباحثة نظريـة سـوليفان (Sollivan) ومـن خـلال مراجعـة دراسـات سابقة ذات علاقة بموضوع البحث تمت صياغة فقرات المقياس بصيغتها الأولية والمكونة من (32) فقرة توزعت على مجالين بواقع (16) فقرة لكل مجال , وقد روعي عند صياغة الفقرة، إن تكون واضحة ذات معنى محدد، إن تكون متعلقة بالموضوع المراد قياسـه (ابو

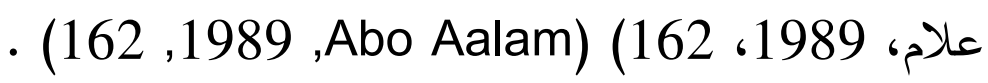

\section{صلاحية الفقرات}

للتعرف على مدى صلاحية فقرات المقياس عرضت بصيغتها الأولية على (10) خبراء في الإرشاد النفسي والطب النفسي للحكم عليها وإبداء آرائهم حول صلاحية الفقرات , وبعد جمع الآراء المحكمين تبين ان (24) فقرة بواقع (12) فقرة لكل مجال قد نالت على التى نسبة اتفاق (80\%) فأكثر ولم تحصل (8) فقرات بواقع (4) فقرة لكل مجال على نسبة الاتفاق المطلوب , لذا تم حذفها من المقياس وأصبح المقياس يتألف من (24) فقرة ـ العينة الاستطلاعية :

اختارت الباحثة (20) مراجعاً من مرضى الاكتئاب العصابي بصورة عشوائية من مراجعي مستشفى ابن الرشد للإمراض النفسية بغداد , بواقع (10) ذكور و (10) إناث تم جمعهم في حديقة المستشفى لغرض معرفة مدى وضوح التعليمات والفقرات للمستجيبين , وقد تبين أنها واضحة ومدى الوقت المستغرق تراوح بين (15-20) دقيقة . تصحيح المقياس :

ويقصد بـه وضع درجة لكل بديل من البدائل الثلاثة التي تم تحديدها وهذه البدائل هي (تتطبق كثيراً , تتطبق إلى حد ما , لا تتطبق ابدآ) اذ تم اعتماد الاوزان الاتية: (1- 
2-3) بعد استشارة ذوي الخبرة والاختصاص، اذ يكون أعلى مدى نظريـة للمستجيبين على المقياس هو (72) درجة وأدنى درجة (24) و الوسط الفرضي للمقياس هي (48) درجة . التحليل الاحصائي للفقرات: يشير اييل (Ebel) الى ان الهدف من التحليل الاحصائي للفقرات هو الابقاء على الفقرات الجيدة في المقياس التي تكثف عن الدقة في قياس مـا وضـعت من اجل مل من قياسه (Ebel), 1972: 392).

تعد القوة التمييزيـة للفقرات ومعاملات صدقها اهم الخصـائص القياسية التي ينبغي التحقق منها في فقرات مقياس الشخصية (الكبيسي، 1995، 5) (Alkubaisy), 1995,

لذا ينبغي التحقق من القوة التمييزية للفقرات ومعاملات ارتباط درجة الفقرات بالدرجة

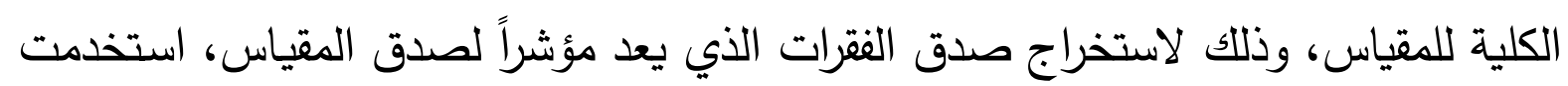
الباحثة اسلوب العينتين المتطرقتين في عملية تحليل الفقرات وذلك وفق الخطوات الاتية: 1. تطبيق المقياس على عينة بلغ عددها (150) من مرضى الاكتئاب .

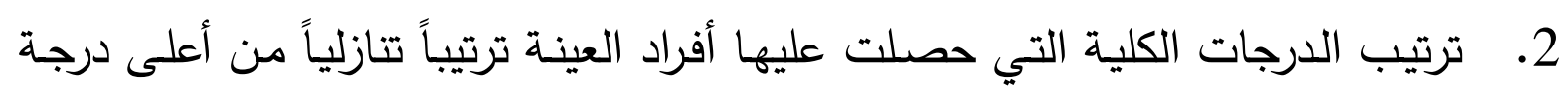
إلى أدنى درجة .

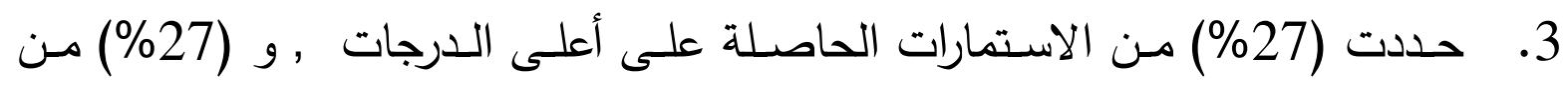
الاستمارات الحاصلة على أدنى الدرجات , وفي ضوء هذه النسبة بلغ عدد الاستمارات في كل مجموعة (40) استمارة ، اذ بلغ عدد الاستمارات في المجموعتين (العليا والدنيا) (80) استمارة.

4. وباستخدام الاختبار التائي لعينتين مستقلين استخرجت القوة التمييزيـة لكل فقرة من

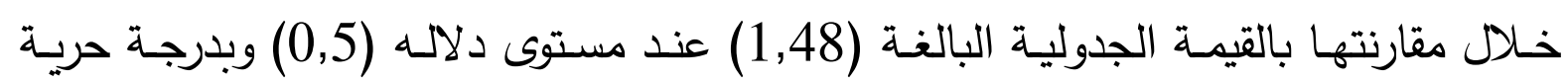

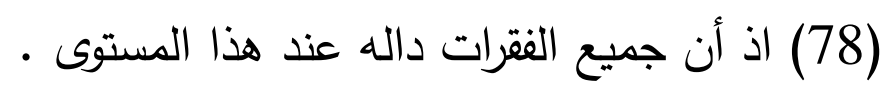
مؤشرات صدق وثبات المقياس : يتفق المختصسون في القياس والتقويم النفسي على أن

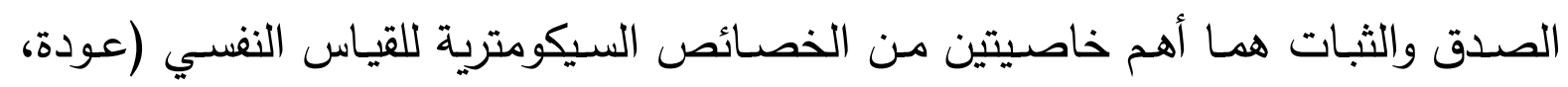


2002، 33) (Audaa, 2002, 33) وقد تحققت الباحثة من الخصائص السيكومترية المقياس على النحو الاتي:تم تطبيق التجربة الاستلاعية يوم الاربعاء المصادف 2017/9/8

$$
\begin{aligned}
& \text { أولاً : صدق المقياس : } \\
& \text { وقد اعتمدت الباحثة في التحقق من صدق المقياس بمؤشري:- }
\end{aligned}
$$

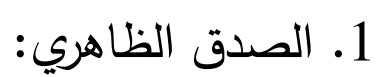

الصدق الظاهري : يمثل مدى دقة التعليمات وما تتمتع به من موضوعية ـ (الغريب،

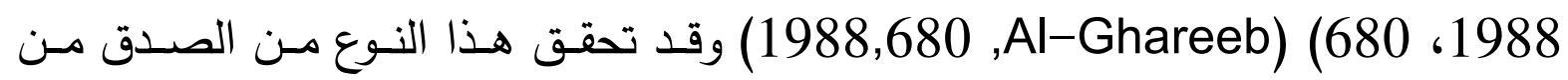
خلال عرض فقرات المقياس وتعليماته وبدائله على مجموعة من الخبراء والمحكمين، وقداع أعدت نسبة اتفاق (80\%) فأكثر معيار للقبول , وبذلك تحقق الصدق الظاهري للمقياس .

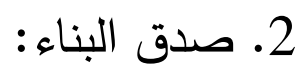

صدق البناء : هو محاولة الانتقال من الثلك في إن الاختبار يقيس ألسمه التي اعد لقياسها

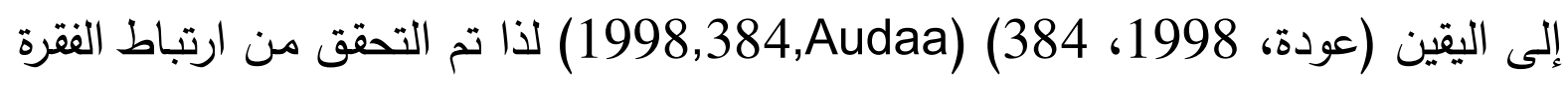
بالدرجة الكلية للمقياس ودرجة ارتباط الفقرة بدرجة المجال وكما يلي : 1-علاقة درجة ارتباط الفقرة بالدرجة الكلية للمقياس : ان ارتباط درجة الفقرة بالدرجة الكلية للمقياس يعني ان الفقرة تقيس المفهوم او السمة الذي الذيائ

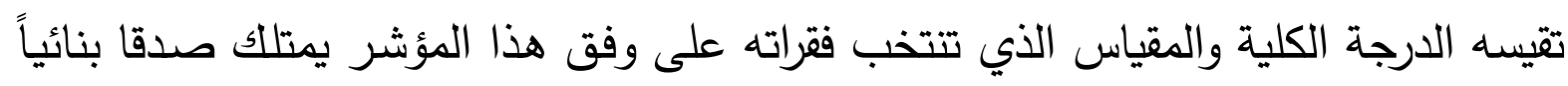
(فراج، 1980، 312)(1980.Farraj) العينة على كل فقرة من فقرات المقياس ودرجاتهم الكلية استخرج معامل ارتباط بيرسون بين درجاتهم الكلية على المقياس وكانت جميع معاملات الارتباط دالة إحصائيا عند مستوى لترى

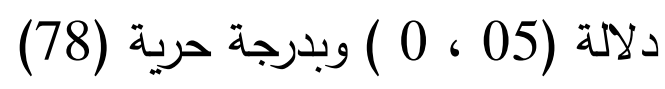

2. علاقة درجة النقرة بدرجة الدجال : 
تم استخراج العلاقة الارتباطية بين درجات كل فقرة والدرجة الكلية للمجال الذي توجد فيه , اذ تم حساب معامل ارتباط بيرسون بين كل فقرة والمجموع الكلي للمجال الواحد الذي توجد فيه الفقرة , وكانت جمع الارتباطات دالة عند مستوى دلاله (0,5) وبدرجة حرية (78) .

ثانياً : ثبات المقياس : يعد الثبات من المؤشرات المهمة في دقة المقياس، والثبات يعني الدقة والاتساق في درجات المقياس لقياس ما يجب قياسه (1991,60,Holt) وبناء على ذللك حرصت الباحثة على التحقق من ثبات المقياس واستعلمت الباحثة أكثر الطرائق شيوعاً وكما يلي :1. طريقة الاختبار - أعادة الاختبار

أن طريقـة الاختبار في إعادة الاختبار أحدى الطرق الثـائعة في حساب الثبات آذ أنها تكثف عن مدى استقرت النتائج عند تطبيق المقياس على مجموعة معينة ولأكثر من مرة

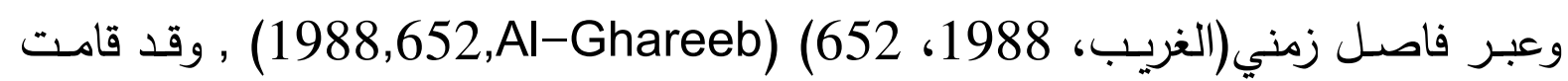
الباحثة بتطبيق المقياس على مجموعة من مرضى الاكتئاب العصابي البالغ عددهم (20)

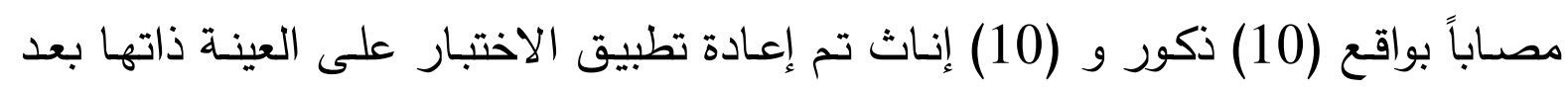
تحديد الأسماء والاستمارات وتم احتساب معامل ارتباط بيرسون بين درجات التطبيق الأول والتطبيق الثاني اذ بلغ معامل الارتباط (0,83) وهو معامل ثبات جيد.

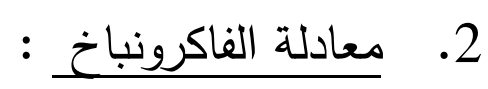

تشير هذه الطريقة الى حساب الارتباط بين جميع فقرات المقياس , اذ ان الفقرة عبارة عن مقياس قائم بذاته , وبذللك يعد مؤشر على اتساق استجابات الفرد والتجانس بين فقرات المقياس (2000,254,Audaa) وعند حسـاب معامل الثبات بهذه الطريقة كانت النتيجـة (0,80) وتشير هذه النتيجة الى ثبات جيد للمقياس. المقياس بصيغته النهائية: اصبح المقياس في صورته النهائية مكون من (24) فقرة، موزعة لهات على مجالين هما: المجال النفسي يتكون من (12) فقرة، والمجال الاجتماعي يتكون من (12) فقرة، اما تدرج الاجابات تكون من ثلاث تدرجات وهي على الترتيب (لا تنطبق ابداً،

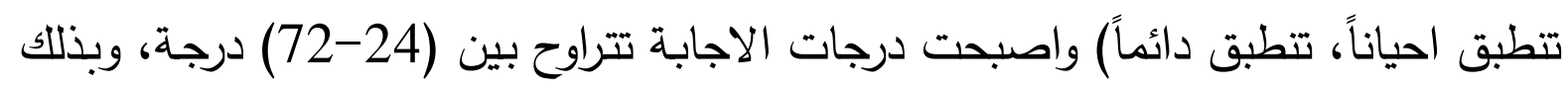


تكون الدرجة القصوى للمقياس هي (72) درجة والدرجة الدنيا (24) درجة وبمتوسط نظري (48) درجـة وبهذا اصبح المقياس جاهزاً للتطبيق على عينـة البحث الحالي وهم مرضى الاكتئاب.

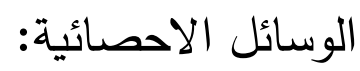

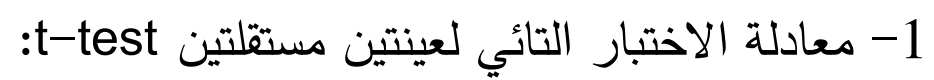
وقد استخدم لاستخراج القوة التمييزية لفقرات المقياس ولحسـاب دلالة الفرق بين المجموعة العليا والمجموعة الدنيا. 2- معامل ارتباط بيرسون:

استخدم لايجاد العلاقة بين درجة كل فقرة والدرجة الكلية للمقياس وكذلك العلاقة بين درجة كل مجال والدرجة الكلية للمقياس واستخدم لحساب معامل ثبات المقياس ولصورتيه في البناء. (1988,168,Al-Ghareeb) 3- معادلة الفاكرونباخ: لاستخراج الثبات. 4- الاختبار التائي لعينـة واحدة: استخدم لإيجـاد الفرق بين الوسط الحسـابي والمتوسط النظري للمقياس. (1985,105,Al-Kendy)

$$
\text { البحنامج الرابع }
$$

تصميم الخطة العلاجية :

يستتد عمل البرنامج العلاجي على دعامتين أساسيتين هما :

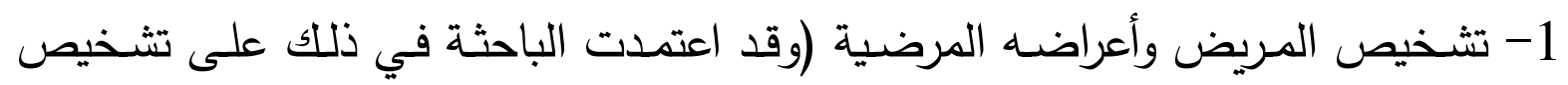
الطبيب النفسي للاكتئاب) وحالة المريض الراهنة ومشكلاته التي طلب العلاج من أجلها. 2- تقسيم فترة العلاج الى ثلاثة مراحل والجدول (1) يوضح مراحل العلاج : 
جدول (1) مراحل العلاج وأهداف كل مرحلة

\begin{tabular}{|c|c|c|}
\hline نهاية العلاج & منتصف العلاج & 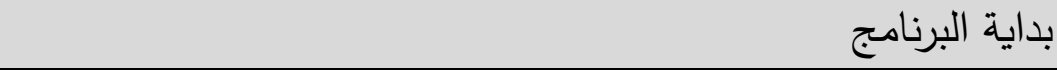 \\
\hline - التـرك & - - التعـرف على & - اقامـه علاقـة علاجيـة تقوم على أسـاس الـودة والقبول والاحتـرام \\
\hline يــز علـى & 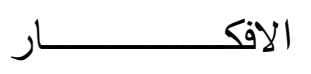 & 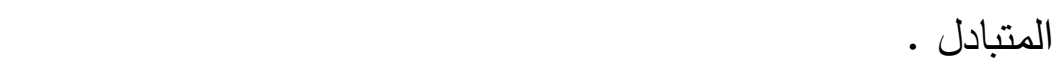 \\
\hline إنهاء العلاج & اللاعقلانيــة لــدى & - التعـرف علـى أهـداف المراجـع مـن العـلاج مـن خـلال تحديــهـا \\
\hline والعمل على & المراجـع وتقييمهــا & والمشاركه معه في حل المشكلات التي يعاني منها قدر الإمكان . \\
\hline من & والتعـاون معـهـ مـن & -شـرح المـرض وطبيعـة أعراضــهـ ومســاعدة المراجـع على كيفيـة \\
\hline \multirow[t]{5}{*}{ 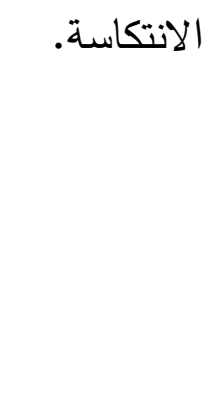 } & اجـل تصــحيحها & التعرف على الافكار اللاعقلانية وتقييمها وتصحيحها ـ. \\
\hline & من خلال استعمال & - اعداد المراجع لتقبل الواجب المنزلي \\
\hline & الوسائل المناسبة . & - اعـداد المراجــع لتقبـل عمـل الأنثـــة التــي يتضــــها البرنــامج \\
\hline & & العلاجي. \\
\hline & & - اعلام المراجع بالنتيجه وتزويده بالمعلومات اللازمه \\
\hline
\end{tabular}

تكوين البرنامج العلاجي:

يتضمن البرنامج العلاج العقلاني الانفعالي السلوكي وفق انموذج اليس (14) جلسة علاجية تشتمل على عدة مراحل وقد تم تقسيمها حسب مراحل العلاج والجدول (2) يوضتح ذلك.

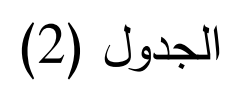

البرنامج العلاجي وفق مراحل العلاج

\begin{tabular}{|c|c|c|}
\hline الإجراءات & عدد الجلسات & المرحلة \\
\hline 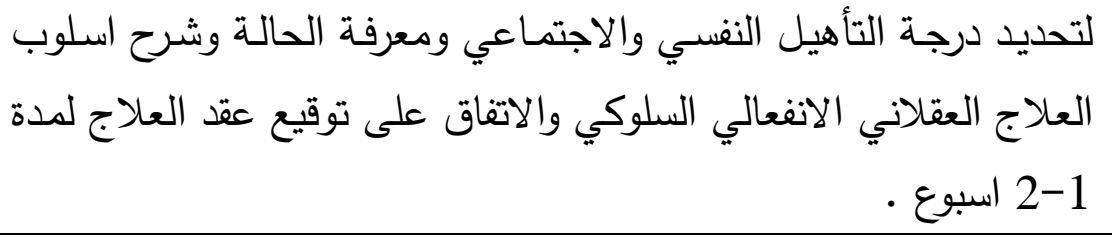 & جليتــــــــان & التشخيص \\
\hline لفترة شهرين ونصف بمعدل جلسة واحدة اسبوعياً & 10 جلسات & مرحلة العلاج \\
\hline 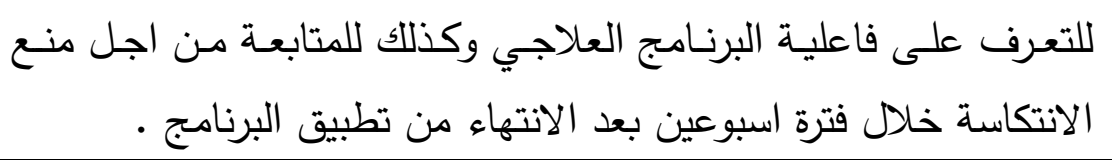 & جلستان & مرحلة المتابعة \\
\hline
\end{tabular}




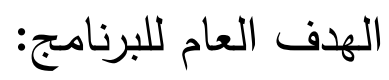

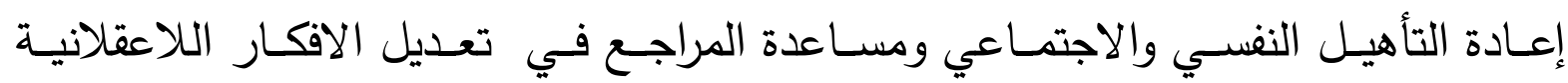
واستبدالها بافكار عقلانية اخرى ومنع الانتكاسـة مما يسهل من عمليه الثفاء من اعراض الاكتئاب .

الاهداف الخاصة: 1. إعادة التأهيل النفسي والاجتماعي بواسطة تطبيق مقياس التأهيل النفسي والاجتماعي . 2. ان تخفف الأعراض المرضية لدى مرضسى الاكتئاب عن طريق تصحيح المعتقدات الخاطئة والافكار اللاعقلانية. الجلسات التمهيدية:

تعد الجلستان التمهيدية ركيزة اساسية في العـلاج العقلاني الانفعالي السلوكي اذ يتم عن طريقهما التعرف على الصعوبات والمشكلات التي يواجهها المراجع واعراض الاكتئاب الذي يعاني منها كل فرد ، وقد استعانت الباحثة في الحصول على المعلومات عن طريق الملف

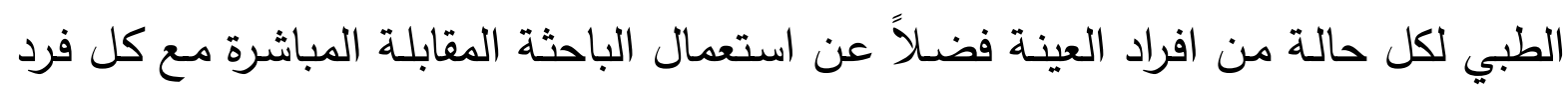
من افراد العينة واسرهم للحصول على معلومات دقيقة وشاملة كإحدى وسائل جمع البيانات وقد حددت الاهداف العامة من العلاج وهي : 1. اقامة علاقة ثقة واحترام متبادل مع المراجع قائمة على الثقة والاحترام المتبادل . 2. شرح طبيعة العلاج العقلاني الانفعالي السلوكي وذلك من اجل تهيئة المراجع لتقبل العلاج.

3. التحدث مع المراجع عن حالته المرضية وعن اسلوب العلاج العقلاني للعالم اليس. 4. غرس الامل والتفاؤل في نفس المراجع وافهام المريض بأن حالته عادية وان المرض وعر

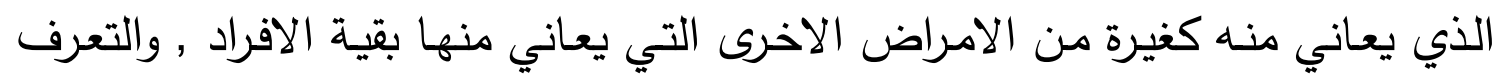

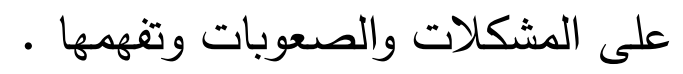
5. ضـرورة افهام المريض بأن العملية العلاجية محددة ضمن وقت معين وأن البرنـامج العلاجي ليس ما لا نهاية. 
اجراءات الجلستان التمهيدية: - الت

- - الترحيب بالمراجع وتعريف الباحثة بنفسها وتخصصها - - التعريف بالهدف من المقابلة وطمأنة المراجع بسرية المعلومات التي سيخبرها للباحثة

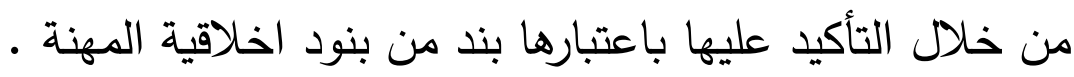

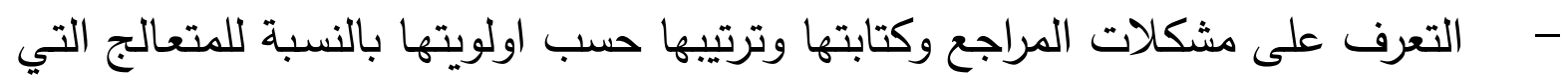
تتضمن الجوانب النفسية والاجتماعية والاسرية والصحية والثخصية والمهنية ـ وتنظيمها ضمن مجموعات ليسهل تتاولها خلال الجلسات العلاجية .

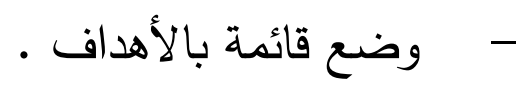
- عقد اتفاق مع كل مراجع على عدد الجلسات ومراحل العلاج والوقت والتاريخ الذي سيتم عن طريقه بدء جلسات مرحلة العلاج. - التحضير للجلسة الأولى: 1. مراجعة الملفات الخاصـة بالمراجع وتتضمن (الملف الطبي والنفسي الموثقة في سجله الخاص به في مستشفى ابن رشد للأمراض النفسية . 2. التشخيص الدقيق ومستوى الاكتئاب الذي يعاني منه المراجع لتحديد مستوى العـلاج العقلاني الانفعالي السلوكي الذي يحتاج اليه . الجلسة/ الخامسة عنوان الجلسة/ القوة والسيطرة زمن الجلسة / 45 - 60 دقيقة

\begin{tabular}{|c|c|}
\hline التفصيلات & 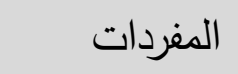 \\
\hline - - الحاجة الى تعديل مفهوم المراجع عن الصعوبة والعجز وضعف الحويل الصارادة . & 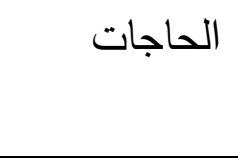 \\
\hline تتمية الشعور بالقوة والسيطرة لدى المراجع • & الهدف العام \\
\hline ان يتمكن المراجع من:- & 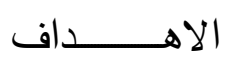 \\
\hline - - تصحيح مفهومه عن الصعوبات والعجز وضعف الارادة & 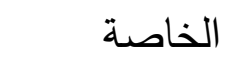 \\
\hline - تحويل الصعوبات والعوائق والشعور بالعجز الى حالة من السيطرة والقوة. & \\
\hline 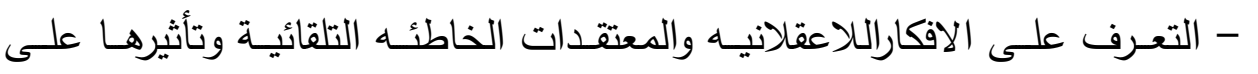 & \\
\hline
\end{tabular}




\begin{tabular}{|c|c|}
\hline الحوارات الداخلية. & \\
\hline - الحوار الذاتي , الاسترخاء , التخيل العقلاني , لعب الدور • & التقنيـيـــــــات \\
\hline 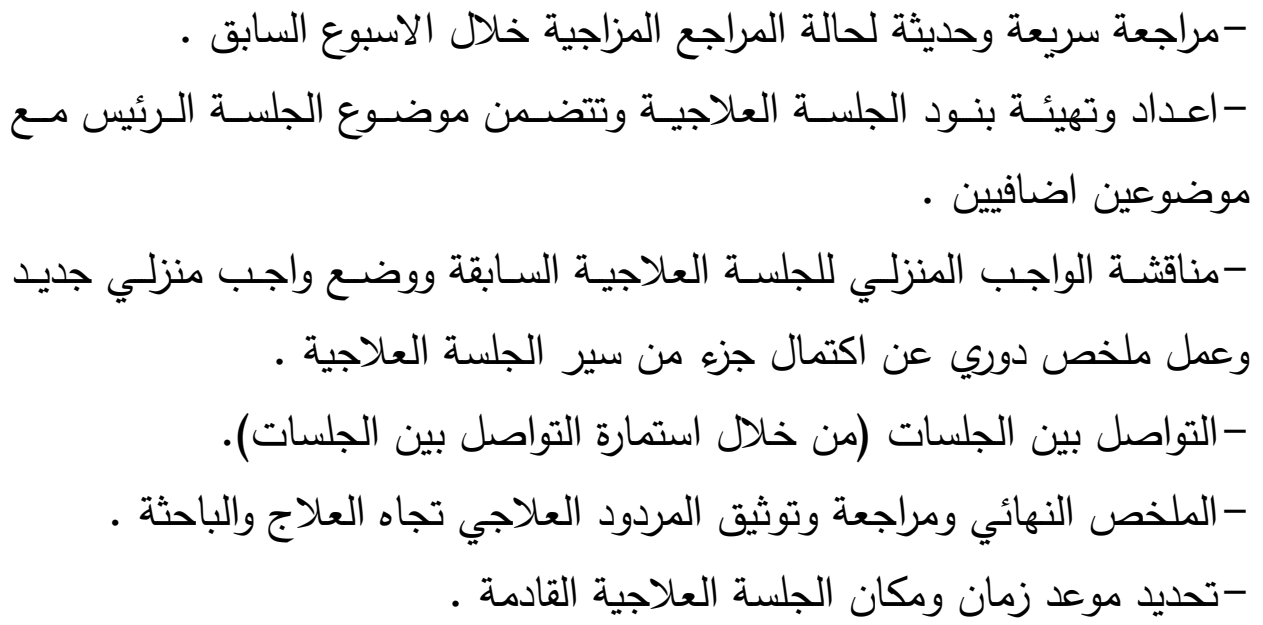 & بنود الاجندة \\
\hline - - جدولة النشاطات (التي تخص الصعوبات والعوائق والشعور بالعجز) . & 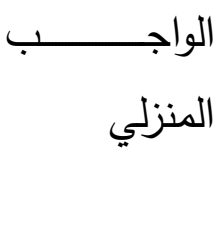 \\
\hline
\end{tabular}

ادارة الجلسة

- - الترحيب بالمراجع وتبادل التحية معه ومراجعة الحالة المزاجية . - مناقشـة الواجب المنزلي والتعرف على الصعوبات والمشكلات التي واجهته أثناء تأدية الواجب ومساعدته على التغلب عليها قدر الإمكان مع تقديم الدعم والتشجيع له لزيادة

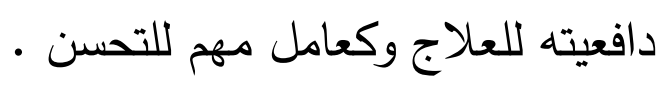
- - تحديد الأفكار اللاعقلانية وتبصير المراجع وزيادة وعيه بتقنيتي الحوار الذاتي والتخيل العقلاني وذلك بهدف حصر المعتقدات اللاعقلانية والعمل على صياغة معتقدات جديدة توافقية . - - بعد التعرف على الأفكار اللاعقلانية والمعتقدات الخاطئة عملت الباحثة على تشجيع

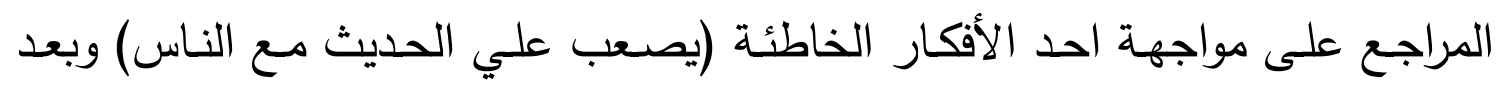
التعرض التدريجي يتم استعمال تقنية الاسترخاء لتخفيف التوتر الناتج من التعرض . 
وبتقنية لعب الدور تم التعرف على الأفكار التي ينتقد بها نفسه ويشعر بالعجز عند

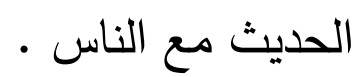

- - دربـت الباحثـة المراجـع على مهـارات التواصـل الاجتمـاعي مـن خـلال تركيز انتبـاه المراجع على خبرات النجاح وتحسين الحديث الذاتي الإيجابي عن الذات من خـلال

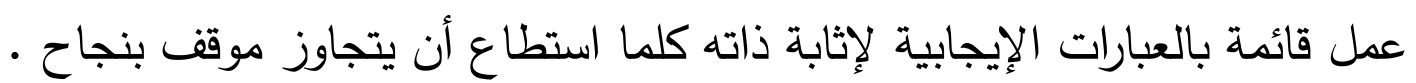
- - بعد اكتمال جزء من الجلسة طلبت الباحثة من المراجع تلخيص جزء من سير الجلسة لإنة

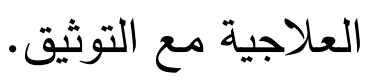
- - ملخص عام ونهائي لما دار في الجلسة العلاجية شفهياً من قبل الباحثة مـع التوثيق

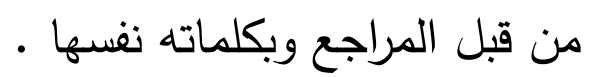

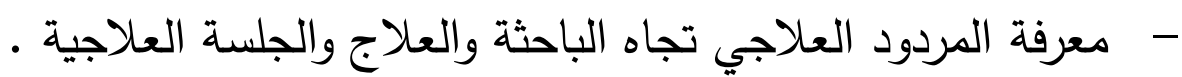
- - تعيين الواجب المنزلي الجديد مع تحديد موعد زمان ومكان الجلسة العلاجية القادمة . 


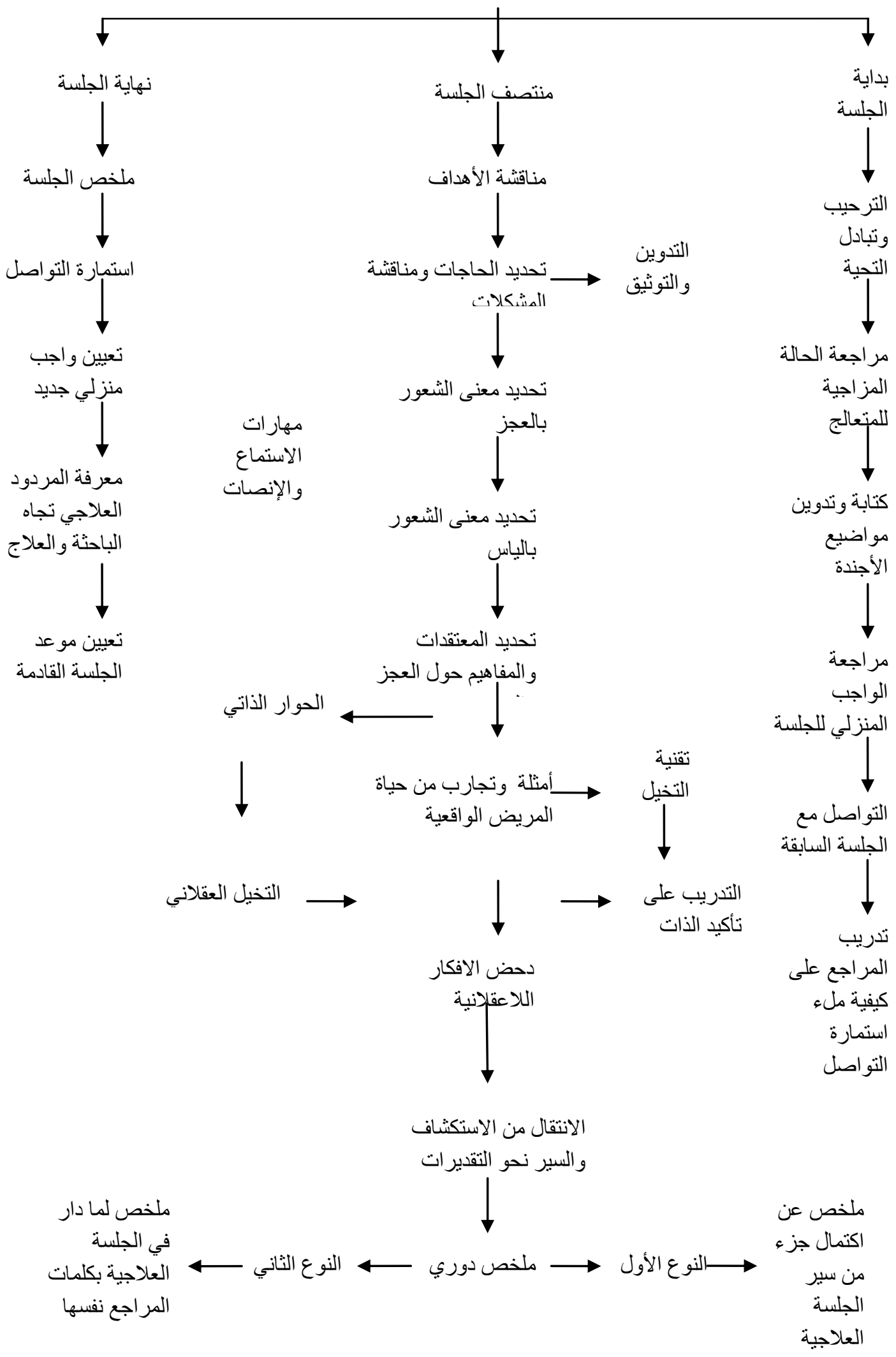

مخطط (5) يوضح سير الجلسة الخامسة 
جلسات المتابعة

الاهداف

- - تقديم الدعم والتشجيع للمراجع على الاستمرار في جلسات العلاج والتحسن الذي وصل اليه.

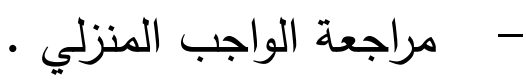
- التعرف على المواقف التي تعرض لها خلال فترة الانقطاع عن العلاج وكيفية تطبيقه لمهارات العلاج السلوكي المعرفي . لمات الاجراءات التي اتخذت في جلسات المتابعة تتمثل كالآتي:

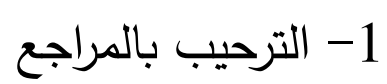
- مراقبة الاعراض ومراجعة جدولة النشاطات وكذلك مراجعة الواجب المنزلي - عرض رسم بياني يظهر سير التحسن لدى المراجع مقترناً ذلك بالمناقشة والشرح والتقييم

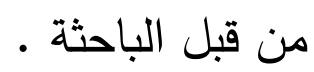

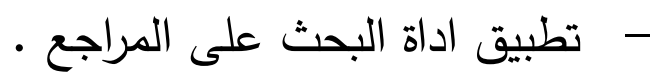
- شرح المراجع للمواقف الحياتية المختلفة التي تعرض لها للتعرف على كيفية تطبيقه لمهارات العلاج السلوكي المعرفي على تلك المواقف . - مراجعة اهم الموضوعات التي تمت مناقشتها خلال الجلسات السابقة وترتيبها حسب ل

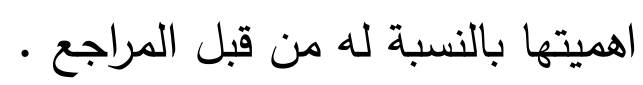
- تقسيم المراجع للمشكلات والصعوبات التي يواجهها مستقبلاً إلى مجموعات ليسهل تتاولها والتوصل الى حلول مناسبة لها وذلك من خلال تدريبه على تجزئة المشكلات

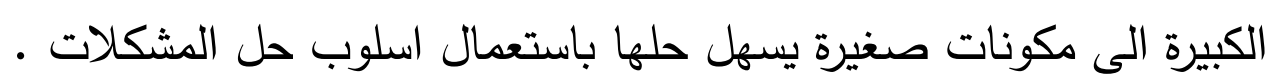
- قدمت الباحثة للمراجع موقف اجتماعي حقيقي وطلبت منه استخدام تقنية التخيل

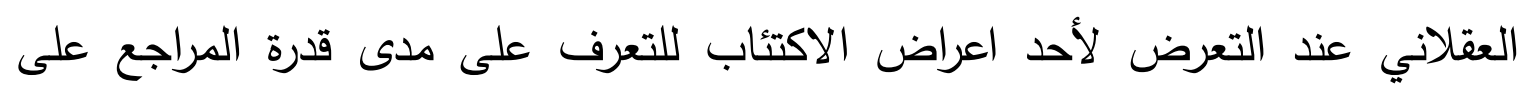
تطبيقها بصورة حقيقية والتعرف على الافكار اللاعقلانية وكيفية التعامل مع تلك الافكار ووضع خطة للتعامل مع هذه الظروف . 
- الطلب من المراجع ذكر اهم الاساليب التي يسهل عليه استخدامها وكيفية تطبيقه لها عند تعرضه لأي انتكاسة محتملة او عودة اعراض الاكتئاب . - الاتفاق مع المراجع على جلسات متابعة اضافية كل (3 , 6 , 12) اشهر , ويمكن ان اعردان

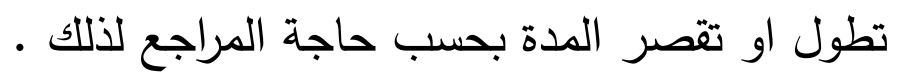

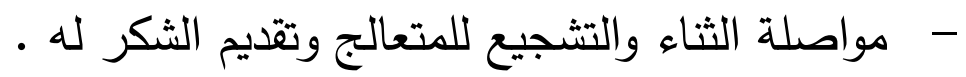
- - الاتفاق على جلسات تدعيمه مع المراجعين كل ثلاث اشهر كاتفاق اولي لضمان سير التحسن لاى المراجع. سيتم عرض نتائج البحث ومناقشتها على وفق الأهداف المحددة كما يأتي:1- قياس التأهيل النفسي والاجتماعي لمرضى الاكتئاب .

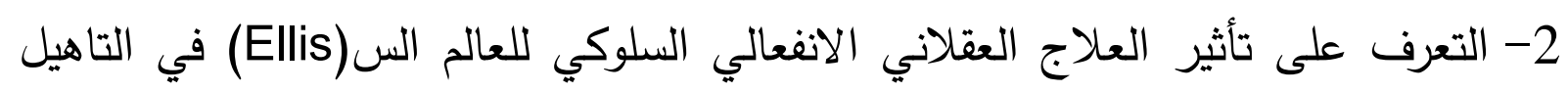
النفسي و الاجتماعي لمرضى الاكتئاب وذللك من خلال التحقق من الفرضية الأتية:1- لا يوجد فرق ذات دلالة احصائية في التأهيل النفسي والاجتماعي لمرضى الاكتئاب قبل تطبيق البرنامج العلاجي وإثناءه وخلال مدة المتابعة (Follow-up) :

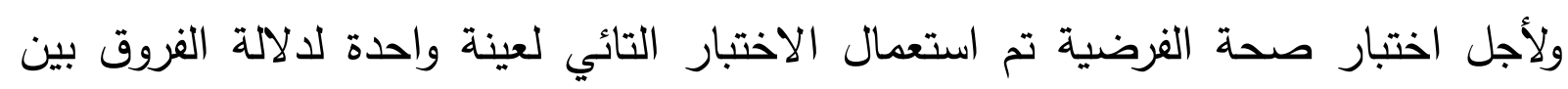

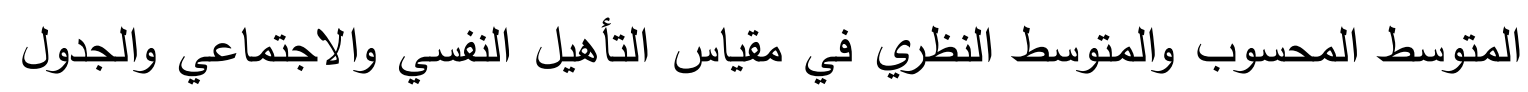

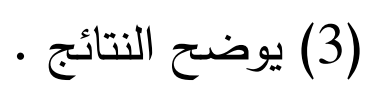

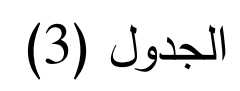

الاختبار التائي لعينة واحدة لدلالة الفروق بين المتوسط المحسوب والمتوسط النظري في

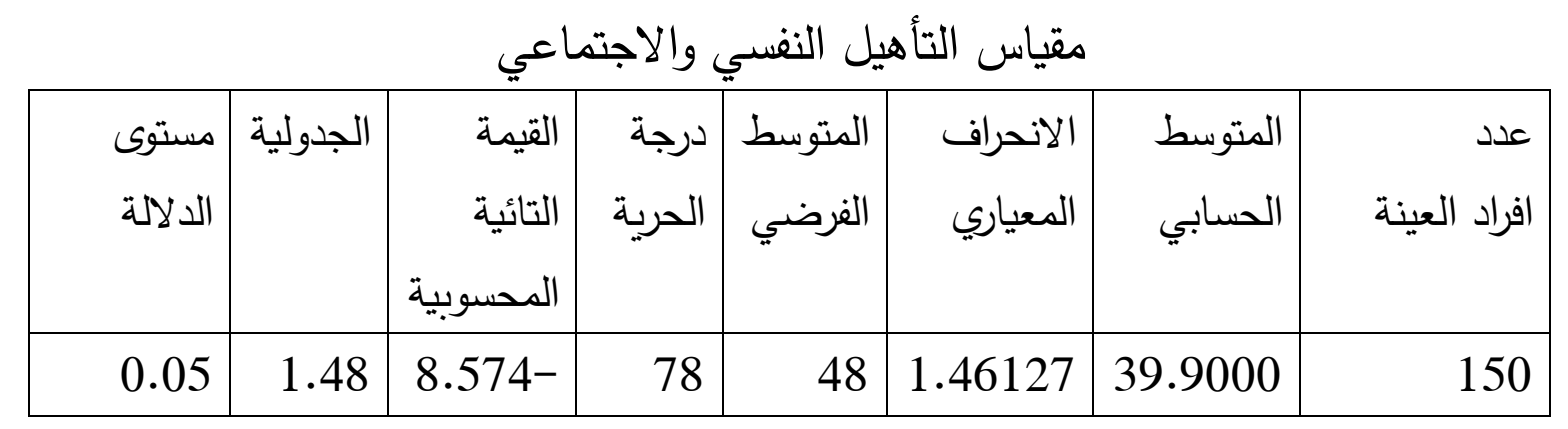

يتضح من الجدول اعلاه ان الوسط الحسابي أقل من الوسط الفرضي وهذا يدل على انخفاض درجة التأهيل النفسي والاجتماعي لمرضى الاكتئاب. 
ملاحظة :سترمز الباحثة لمقياس التأهيل النفي والاجتماعي بالرمز ( P-S-R-M) ((psycho-social rehabilitation measure تمثل الاجابة على الفرضية للمراجع من خلال الجداول الاتية (4) و (5) و (6) لمدة البحث المقسمة الى ثلاث مراحل ( التشخيص والعلاج والمتابعة ) بالتتابع متبوعة بالاشكال البيانية (1) و (2) و (3) و (4) و (5) والتي توضح سير التحسن خلال مراحل البحث الثلاثة. (4) الجدول

درجات مقياس التأهل النفسي والاجتماعي للمراجع خلال مرحلة التشخيص

\begin{tabular}{|c|c|c|c|}
\hline عنوان الجلسة & $\mathrm{P}-\mathrm{S}-\mathrm{R}-\mathrm{M}$ & المدة & مرحلة التشخيص \\
\hline الجلسة التمهيدية الاولى & 27 & الاسبوع 1 & المرحلة الاولى \\
\hline الجلسة التمهيدية الثانية & 27 & الاسبوع 2 & المرحلة الثانية \\
\hline
\end{tabular}

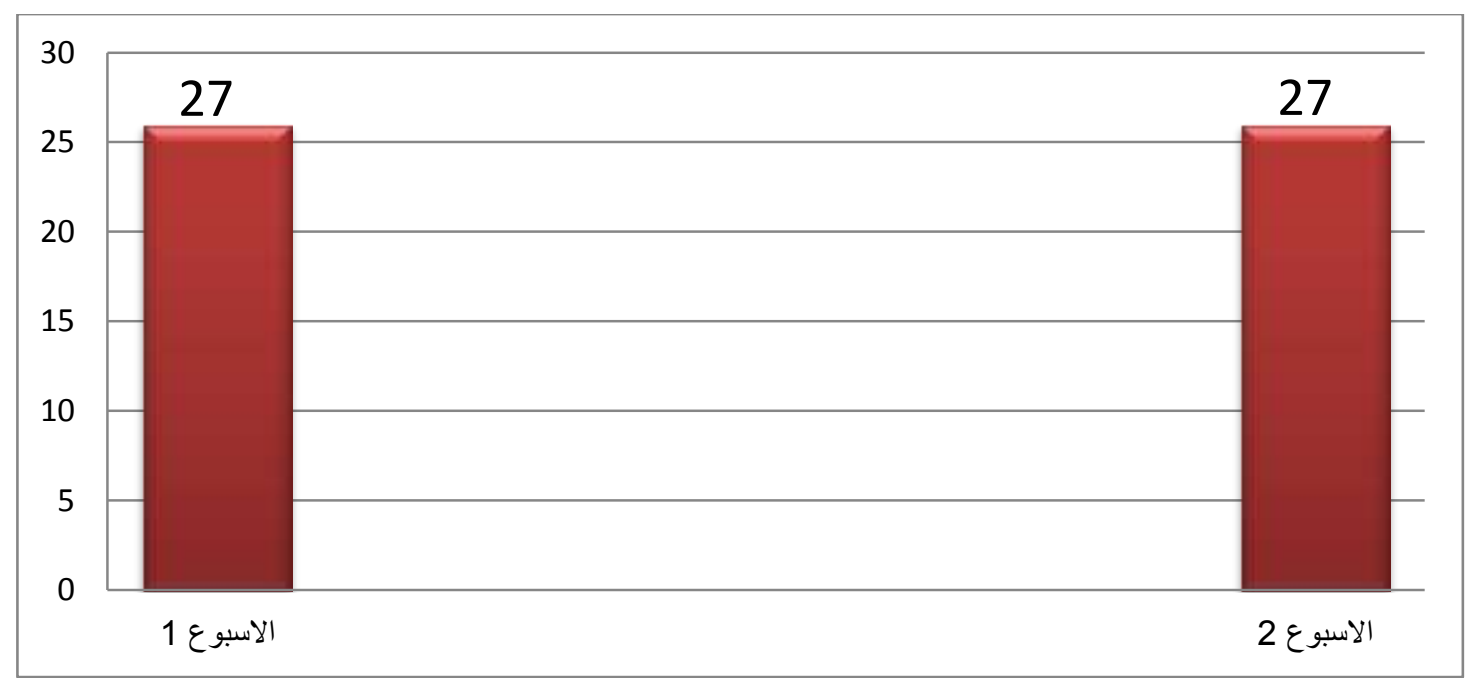

شكل (1) يوضح قيم اداة البحث للمراجع خلال مرحلة التشخيص

مرحلة التشخيص: يلاحظ من الجدول (4) والشكل(1) ان درجة المراجع بلغت على مقياس التأهيل النفسي والاجتماعي (27) درجة كأختبار قبلي وهي تزيد عن الدرجة الدنيا للمقياس بمقدار ثلاث درجات مما اعطى للباحثة توقعا ان تسير عملية تغير وتعديل الأفكار اللاعقلانيه +و ولانيه

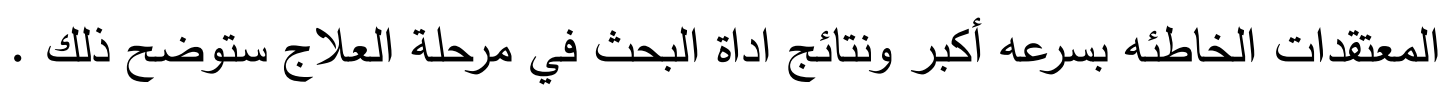


مرحلة العلاج: يوضح الجدول(5) وشكل(2)و (3) درجات اداة البحث خلال مرحلة العلاج.

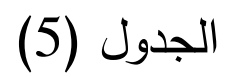

درجات للمراجع على أداة البحث خلال مرحلة العلاج

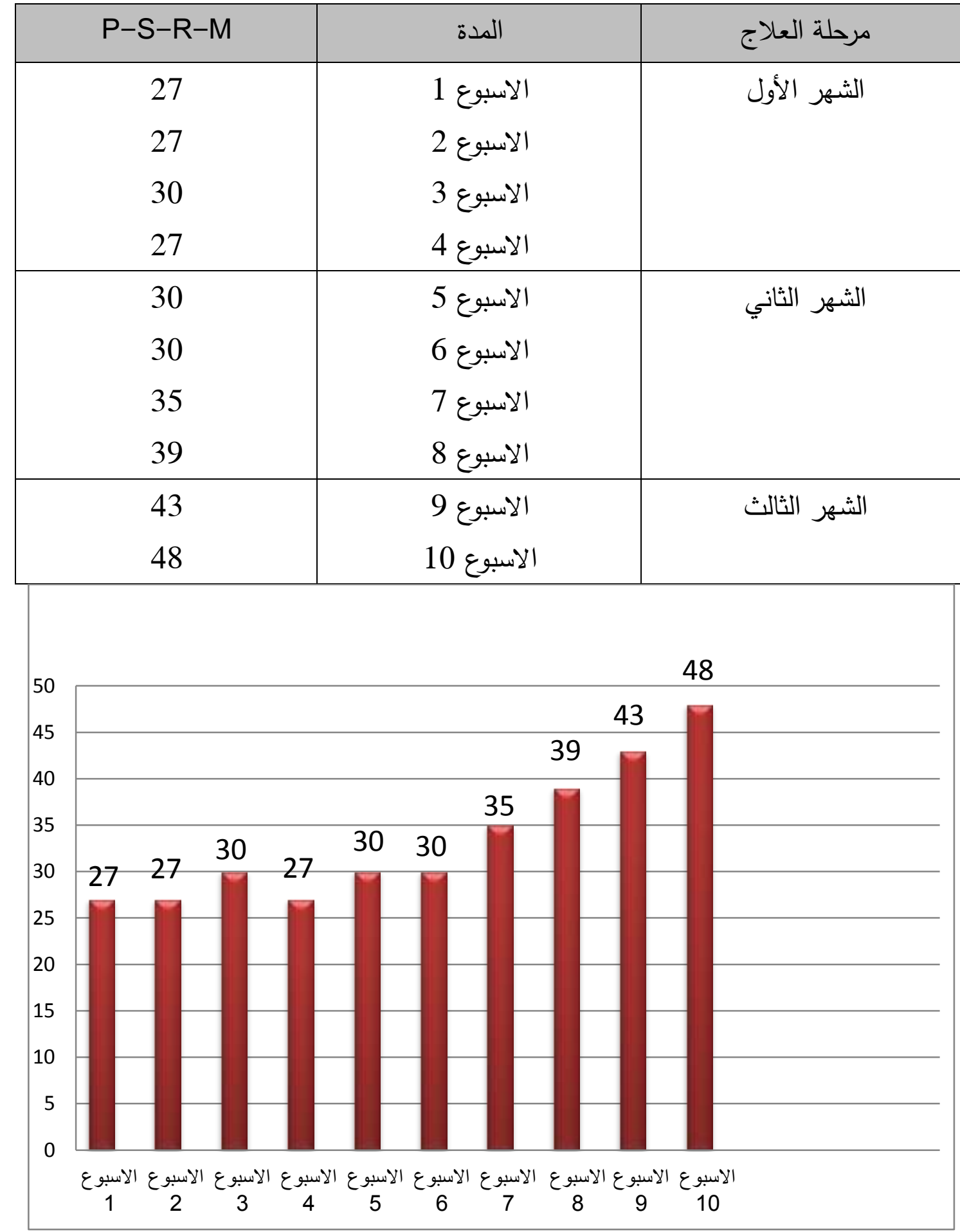

شكل (2) يوضح درجات المراجع على اداة البحث خلال مرحلة العلاج 


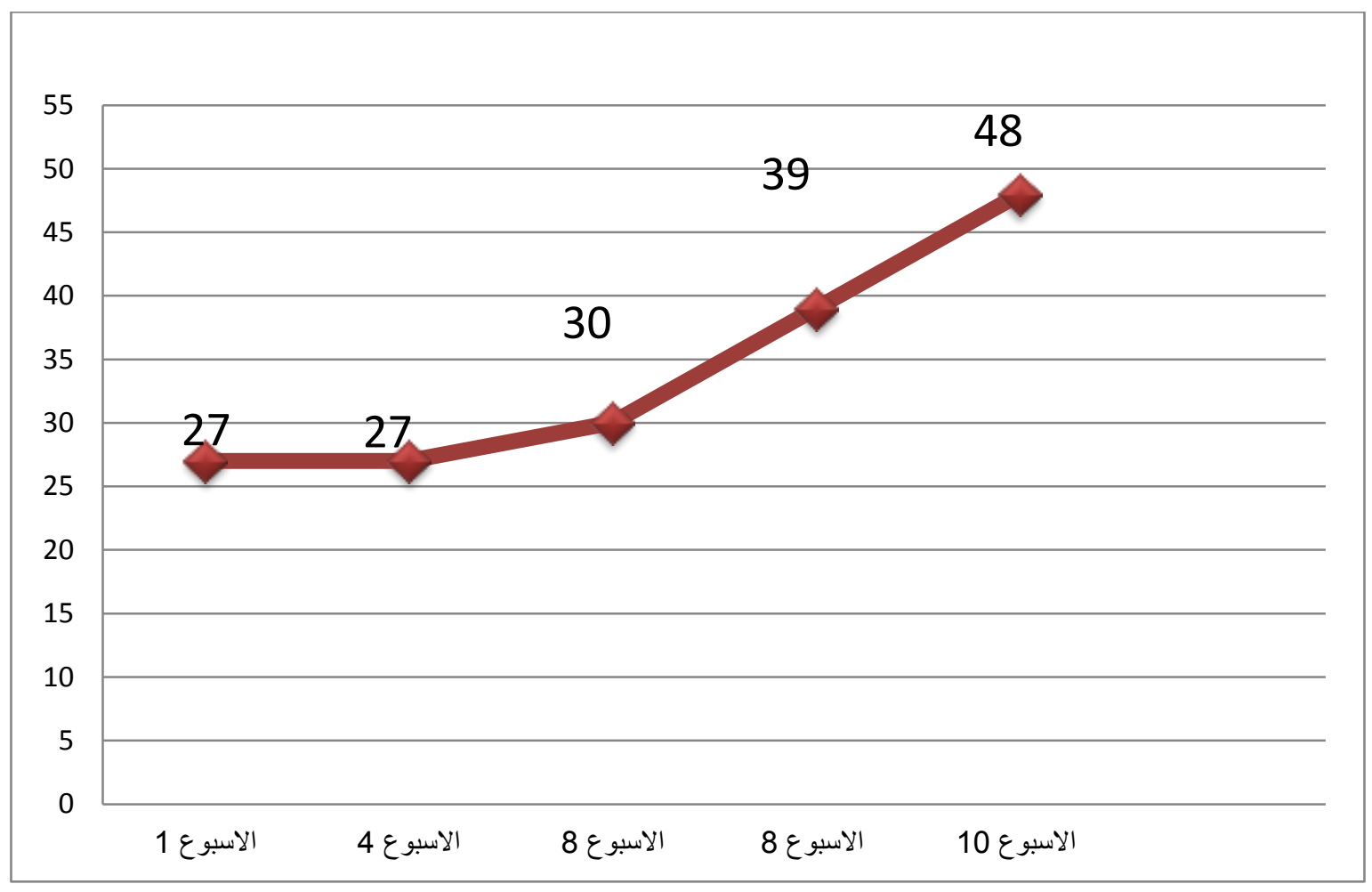

شكل (3) يوضح سير التحسن للمراجع على اداة البحث خلال مرحلة العلاج يلاحظ من الجدول (5) وشكل (2) و(3) من أن درجات المراجع خلال الأسابيع الاربعة

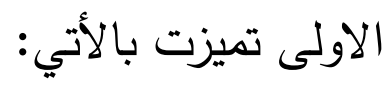
1- التذبذب وعدم الاستقرار وفقا لاستجابة للمراجع على اداة البحث مما يشير الى العلاقة الارتباطية بين الافكار اللاعقلانيه والمعتقدات الخاطئه والاعراض التي يسببها مرض لهن الاكتئاب هذا من جهة ومن جهة اخرى يعود السبب في هذا التذبذب الى الظروف الاسرية وضغوط المجتمع والوصمة التي يسببها مرض الاكتئاب على المريض. 2- جاءت نتائج الشهر الاول من مرحلة العلاج على اداة البحث مخالفة لتوقعات الباحثة ولكن مع استمرار الجلسات العلاجية والقيم التي اظهرتها أداة البحث خلال المدة الباقية من العلاج جاءت النتائج متفقة مع نتائج الدراسات والاطار النظري وتوقعات الباحثة واستمرت عملية التأهيل النفسي والاجتماعي اذا مااخذنا بنظر الاعتبار الاعرض التي يسببها مرض الاكتئاب وعلاقتها بالافكار اللاعقلانيه والمعتقدات الخاطئه وشده الاعتقاد

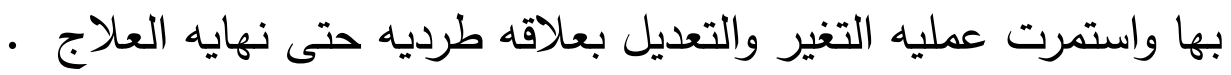
3- نتائج الاختبار القبلي لمقياس التأهيل النفسي والاجتماعي (27)وعلى الاختبار البعدي لهي (48) في الجلسة 10 أي بقيمة مساويه لقيمة الوسط الفرضي مما يعني رفض الفريلية 
الصفرية وقبول الفرضية البديلة وتتفق هذه النتيجة مع الاطار النظري لاسلوب العلاج العقلاني الانفعالي السلوكي للعالم الس (Ellis) من ان تعديل وتغير الافكار اللاعقلانيه والمعتقدات الحاطئه سيرافقه تحسين الحوارات الذاتيه اتلداخليه و تعديل مفهوم الذات و لهويل اكتساب المهارات وبالتالي يؤدي الى حسن التأهيل النفسي والاجتماعي .

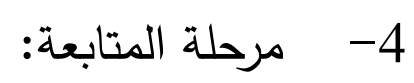

مدتها اسبوعين وقد تم تقسيمها الى مرحلتين للتاكد من سير التحسن. يوضح الجدول (6) وشكل (4) فاعليه البرنامج العلاجي مقدرا بدرجات المراجع على اداه البحث يلاحظ من الجدول(6) وشكل (4) التابع له ما ياتي:

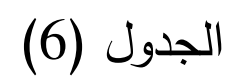

درجات المراجع خلال مرحلة المتابعة

\begin{tabular}{|c|c|c|c|}
\hline عنوان الجلسة & $P-S-R-M$ & المدة & مرحلة المتابعة \\
\hline جلسة المتابعة الاولى & 48 & الاسبوع 1 & الاولى \\
\hline جلسة المتابعة الثانية & 48 & الاسبوع 2 & الثانية \\
\hline
\end{tabular}

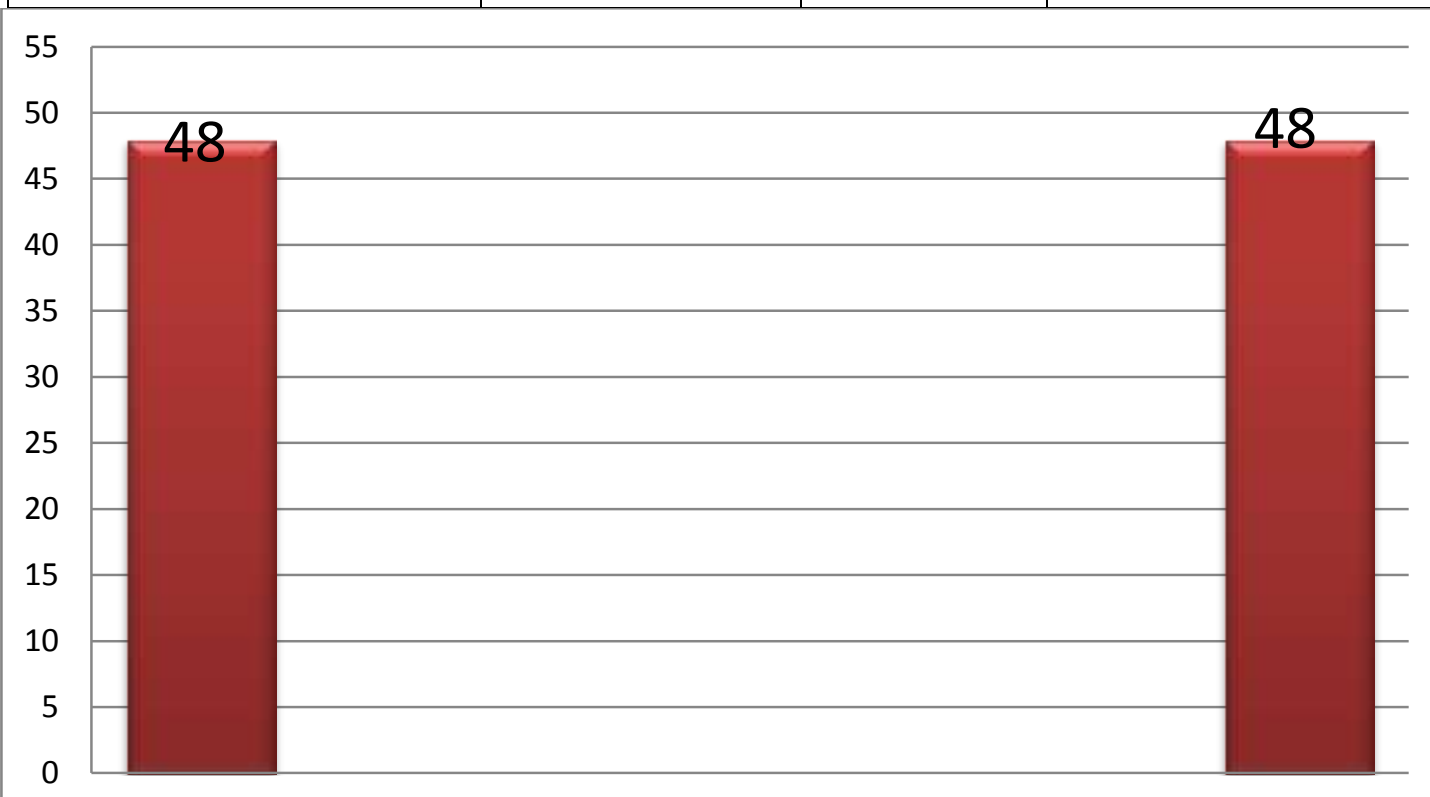

شكل (4) يوضح درجات اداة البحث للمراجع خلال مرحلة المتابعة

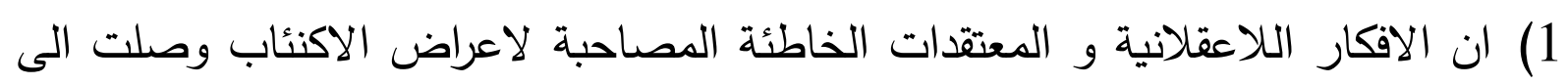

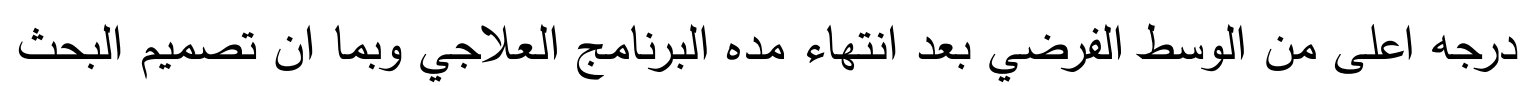


الحالي يتضمن وجود مرحله متابعه يمكن من خلالها التعرف على النتيجه اذ بلغت درجه المراجع على مقياس التأهيل النفسي والاجتماعي (50) درجه ويرجع السبب في هي ذلك الى ان المراجع قد طبق اغلب مهارات العلاج العقلاني الانفعالي التي تعلمها خلال الجلسات العلاجية التي استدل عليها من تقييم الباحثه للواجبات المنزليه في مرحله المتابعه مما ساعد في تغيير الافكار الخاطئة والمعتقدات اللاعقلانية رافق ذلك تحسين الحوارات الداخليه وبالتالي تخفيف الاعراض الاكتئابية. 2) تم تغيير وتعديل الافكار الخاطئه والمعتقدات اللاعقلانيه بقيمه اعلى من درجه الوسط الاعله

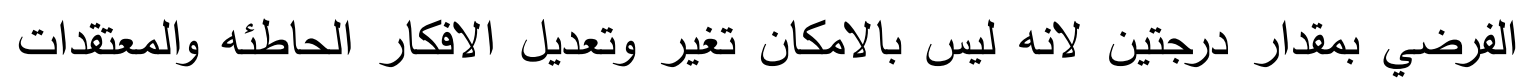
اللاعقلانيه الى صفر \% ولكن بصفه عامه لمعرفه اي تغير في الافكار والمعتقدات

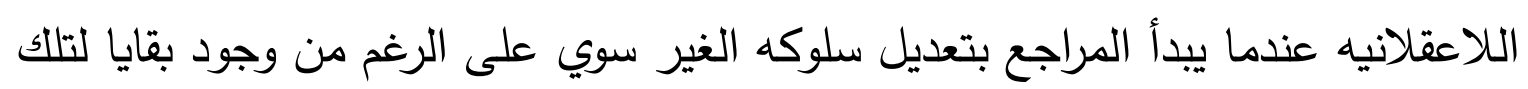
الافكار والمعتقدات الخاطئة. ان وجود مرحله المتابعه في العلاج العقلاني الانفعالي السلوكي اعطت الفرصه لمتابعه اثر العلاج حتى بعد انتهاء مده العلاج

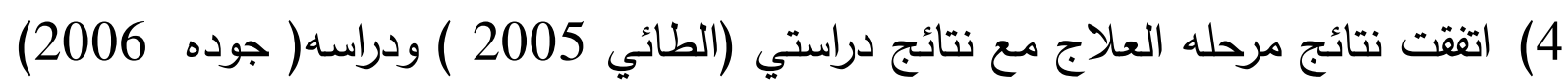
من ان العلاج العقلاني السلوكي يعد علاج مكمل و اساسي في تغير وتعديل الافكار

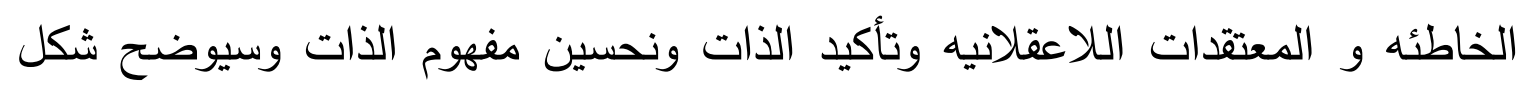
(5) سير التحسن في التأهيل النفسي و الاجتماعي للمراجع خلال مراحل البحث الثلاثة مجتمعة. 


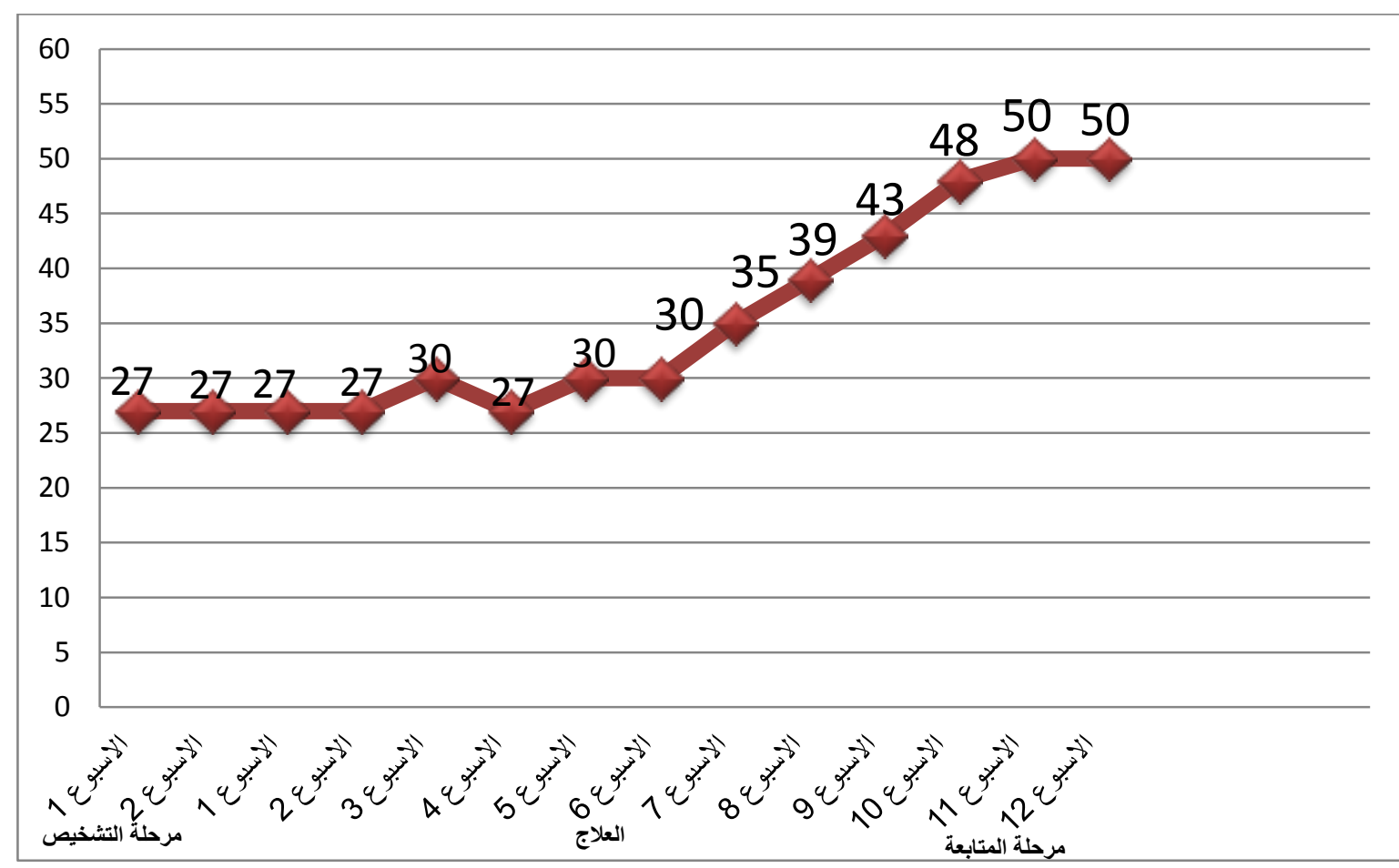

شكل ( 5) يوضح سير التحسن في التأهيل النفسي والاجتماعي للمراجع الاول خلال

مرحلة البحث الثلاثة

الاستنتاجات

في ضوء ما تم عرضه من نتائج تم الخروج بالاستنتاجات الآتية : 1. أن اسلوب العلاج العقلاني الانفعالي السلوكي وما تضمنه من النشاطات والفعاليات المساعدة ، يعد اسلوباً علاجياً ذا فاعلية في نجاح عملية العلاج، والسير نحو التأهيل النفسي والاجتماعي وأفضل خيار علاجي ورئيسي للتخفيف من حدة الأعراض التي - ميسبها مرض الاكتئاب 2. ان نجاح اسلوب العلاج العقلاني الانفعالي السلوكي في التأهيل النفسي والاجتماعي لمرضى الاكتئاب يعد تجربه ناجحة تؤكد على ضرورة الاهتمام بفئه تشكل نسبه كبيره

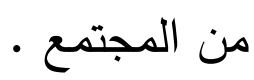
3. ان الافكار الخاطئة والمعتقدات اللاعقلانية لدى مرضى الاكتئاب هي اعراض قابله للتعديل و التغيير اذا ما استعملت معها برامج علاجيه تستتد الى اطار نظري علمي يمكن الاعتماد عليه في هذا التعديل او التغيير. 
التوصيات

1. على وزارتي التعليم العالي والصحة الاهتمام بالعلاج العقلاني الانفعالي السلوكي في الجامعات العراقية ومراكز الاسناد النفسي التابع لوزارة الصحة وإعطائها الرعاية الكافية لاستعمال تلك البرامج العلاجية لتحسين التأهيل النفسي والاجتماعي للمصابين • بالامراض النفسيه 2. مناشدة وزارة التعليم العالي (دائرة الاشراف والتقويم) على حث أقسام الارشاد النفسي في تلادي

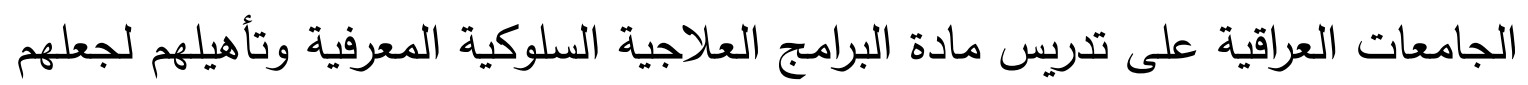
مؤهلين على تطبيقها في المراكز الارشادية في الكليات والجامعات العراقية . 3. مناشدة وزارة الثقافة وهيئة الإعلام والقنوات بضرورة التأكيد على البرامج العلاجية (السلوكية المعرفية) وتثقيف المجتمع بضرورة تقبلها وتقبل المرضى النفسانيين لاندماجهم اسرياً واجتماعياً

المقترحات

استكمالاً لنتائج البحث الحالي إجراء الدراسات الآتية :

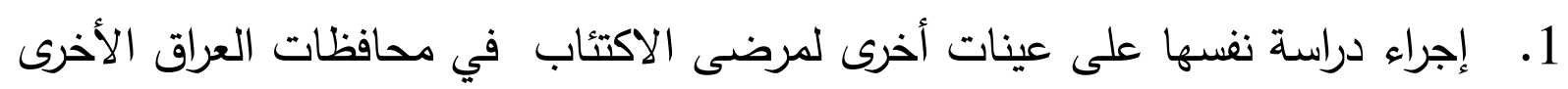

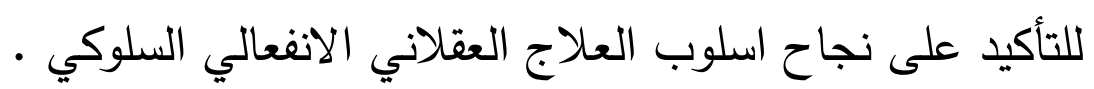

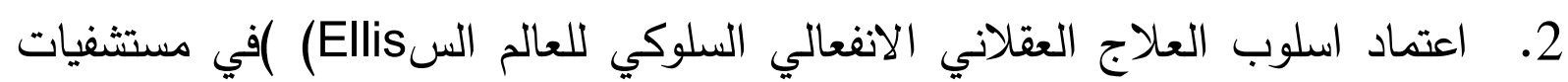

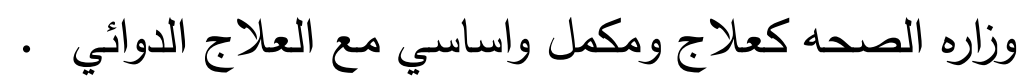
3. الاستفاده من مقياس التأهيل النفسي والاجتماعي في المراكز و الوحدات الارشاديه في الجامعات العراقيه لتشخيص طلبه الجامعه على وفق هذا المقياس . 
المصادر

ابو دلو ، جمال ، (2009)، الصحة النفسية، دار اسامة للنشر والتوزيع، ط1، الاردن-

عمان.

ابو علام ، رجاء محمود (1989) : مدخل الى مناهج البحث التربوي ، ط1 ، مكتبة الفلاح ، الكويت.

أبو لبدة ، سبع ححم (1983) : مبادئ القياس النفسي والتقييم التربوي ، جمعية المطالب

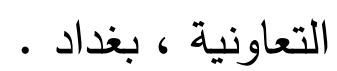
اسعد وابراهيم ، ميخائيل (1987) : المرشد في العلاج النفسي ، منشورات دار الافاق الجديدة ، بيروت باترسون ، س.هـ (1981) : نظريات الارشاد والعلاج النفسي، ترجمة: حامد عبد

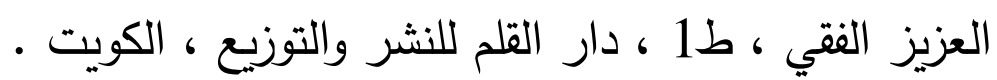
باترسون ، س.هـ (1990) : نظريات الارشاد والعلاج النفسي، ترجمة: حامد عبد

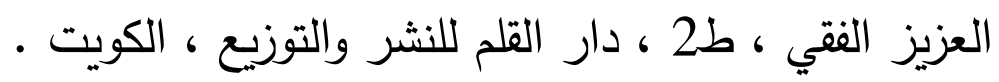
التميمي , محمود كاظم محمود (2009) : كيف تكتب بحثا او رسالة ماجستير , دار الكتب والوثائق , بغداد.

جلال ، احمد سعيد (2008) : مبادئ الاحصاء النفسي ، الدار الدولية للاستثمارات

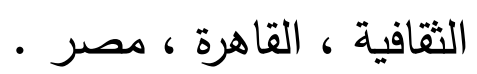
جودة، سعد عزيز ، (2008)، أثر العلاج العقلاني الانفعالي وتوكيد الذات في تتمية الصلاحية النفية، أطروحة دكتوراه غير منشورة ، كلية التربية، الجامعة المستتصرية. الحفني عبد المنعم (1991) : مؤسسة التحليل النفسي , مكتبة مدبولي , القاهرة , مصر. حمصي ، انطوان (1991) : أصول البحث في علم النفس ، مطبعة الاتحاد ، جامعة دمشق ، سوريا.

الخالدي ، اديب محم ، (2015) ، علم النفس الإكلينيكي في التذخل العلاجي ، ط1 ،

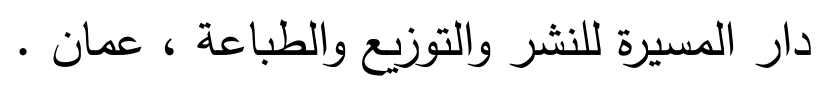


الخطيب , جمال (1995): تعديل السلوك الانساني , ط3, مكتب الفلاح للنشر والتوزيع

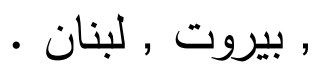
دافيدوف , ليندال (1983) : مدخل الى علم النفس , ط4 , ترجمة : سيد الطواب ومحمود عمر , دار ماكجروهيل للنشر , القاهرة. الداهري , أحمد صالح أحمد (2001) : مبادئ الصحة النفسية , ط2 , دار وائل للطباعة والنشر والتوزيع , عمان , الاردن. داود، عزيز حنا والعبيدي، ناصر هاشم (1990): علم نفس الشخصية، وزارة التعليم العالي والبحث العلمي، مطبعة المعالي، جامعة الموصل. الدليل التشخيصي والاحصائي الرابع للاضطرابات النفسية والامراض العقلية DSM.IV) , 1994.) الرشيدي، بشير صالح والسهل، راشد علي، (2000)، مقدمة في الارشاد النفسي، الطبعة الاولى، مكتبة الفلاح، الكويت. الثاوي، رعد لفتة، قاسم محمد سمور (2000) العلاقة بين السلوك الديني والافكار

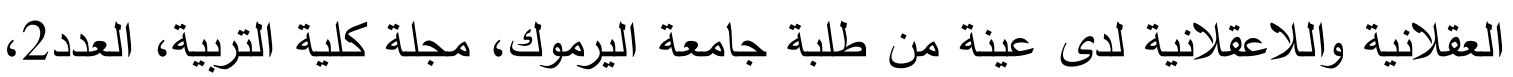
كلية التربية- الجامعة المستتصرية. الصيخان , ابراهيم سالم , (2010) : الاضطرابات النفسية والعقلية , ط1 , دار صفاء

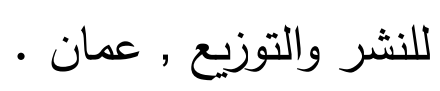
الطائي، عبد الكريم محمود (2005) ، أثر العلاج العقلاني الانفعالي والنمذجة في خفض مستوى الغضب لدى طلاب المرحلة المتوسطة، أطروحة دكتوراه غير منشورة، كلية التربية، الجامعة المستصنية. عباس , فيصل (1982) : الشخصية في ضوء التحليل النفسي , دار المسيرة , بيروت. عباس ، كامل عبد الحميد (1994) : التوافق النفسي لدى طلبة المرحلة المتوسطة وعلاقته بالتحصيل الدراسي ، مجلة التربية والتعليم ، العدد (14) العزة , سعيد حسني وعبد الهادي , جودت عزت (1999) : نظريات الارشاد والعلاج النفسي , ط1 , مكتبة دار الثقافة , عمان • 
عودة , أحمد سليمان والخليلي , خليل يوسف , (2000) الإحصاء للباحث في التربية والعلوم الانسانية , دار الامل , الاردن.

عودة وملكاوي ، فتحي حسن (1992) : اساسيات البحث العلمي في التربية والعلوم

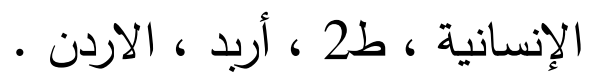

غانم ، محمد حسن (2006) : الاضطرابات النفسية والعقلية والسلوكية ، ط1 ، مكتبة الانجلو المصرية ، القاهرة ، مصر • الغريب، رمزية (1988) التقويم والقياس النفسي والتربوي، مكتبة الانجلو المصرية، القاهرة.

فراج , عثمان لبيب (1970): أضواء على الشخصية والصحة النفسية , ط1, مكتبة النهضة المصرية , القاهرة. هول , كالفن • س وليدزي , جاردنز ، (1978) : نظريات الشخصية ، ترجمة فرح

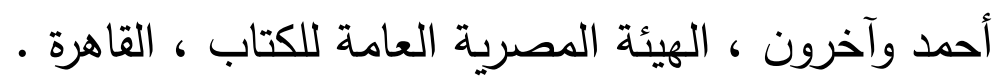

\section{References:}

- Allen , M. H. \& yen. W M (1979) introduction measurement theory, California , Books cole

- Black, S., (1983): short - term counseling: A Humanistic approach for the helping professions, California Addison-Wesley publishing company, medical/ Nursing Division.

- Block, L.\& Dobsone, K., (1988), Historical and philosophical Bases, New york, Guillford press, New york.

- Corey, (1996), Theory and practice of counseling and psychotherapy, New York, Brook/ cole publishing company.

- Davison kat m. (2000). Cognitive therapy for personality disorder. A guide for therapists butter worth Eenmann, new delhi.

- Eble , R , L (1972) : Essentials of Educational measurement, New York, prentice - Hall .

- Edward, C.C \& will, B.B. (1998) irrational beliefs, optimism, pessimism, and psychological distress: Apreliminary examination. 
- Ellis, A., \& Bernard. M (1992), what is rational emotive therapies, New york.

- Ellis, A., (1979), Theory of Rational emotive therapy, New york, Brook/cole.

- Holt, R, R. (1971) Assassin personally, Harcouy Brance jovanorich, New York

- Huffman, K, Very. M.X. Vegnoy (2000): Psychology in Action, New York.

- Miller , D., (1983) : Hand Book of research design and saial measurement, $4^{\text {th }}$ Ed. New York : Longman.

- Rosen, j.c.et al. (1993). Cognitive Behavioral Theraoy for Negative Body image. Behavior Therapy .

- Sahakian, William S. (1976) : psychotherapy and counseling, rannc maihy lellede publishing company cwiogp . 